\title{
Guide for U.S. Exchange Students Studying at the UFRGS Law School
}

\author{
by James L. Bischoff, exchange student at UFRGS \\ from the University of Texas School of Law, January - \\ August 2003
}

I Otientation and General Information

Rio Grande doSul'

Rio Grande do Sul is the largest, mostpopulous, and mostimportant state in the Southem Region of Brazil (composed of the states of Rio Grande do Sul, Paraná, and Santa Catarina). It is the eighthlangest statein the Union territorially, and the fifth largest in population (behind São Paulo State, Rio de Janeiro State, Minas Gerais, and Bahia). It has the fourth-highest per-capita income at $\mathrm{R} \$ 8,341$, behind the Federal District, São Paulo State, and Rio de Janeiro State. The state's geographical area is slightly smaller than that of Arizona.

Rio Grande do Sul is bordered by Uruguay on the south, Argentina on the west, Santa Catarina on the north, and the Adantic Ocean on the east. The climate is subtropical. Seasonal temperature variations are roughly comparable to those in the U.S. South; in the winter it nevergets much below zero and only snows in the sierra, and summer high temperatures regularly reach into the mid-nineties. If you're going to be in Rio Grande do Sul at any ime from May to September; you'll need to bring sweaters and at least one good jacker, or buy them after anival.

The ethnic makeup of the state is markedly different from that of most of the rest of Brazil and, for that matter, the rest of Latin America. In addition to the descendants of Portuguese and Iralian immigrants, the descendants of many Cerman immigrants also live in Rio Grande do Sul; blond-haired, blue-eyed people are ubiquitous. With a population of just over tenmillion, the state is more populous than Michigan and slightly less populous than Ohio. It has the lowest infant mottality rate in Brazil, and continuous investments in education and health have made Rio Grande do Sul the Brazilian state with the highestquality of life and level of human development. Aresident of Rio Grande do Sul is called a gauicho; originally used only to refer to the region's cowboys, the term has since been expanded to designate the state's population ingeneral.

Thestate's economy is strong and varied. It is the country's largest producer of grains (soy, corn, wheat, and rice) and shoes, and it is also an importantproducer of tobacco, petrochemicals, wood and wood products, and automobiles.

Check out www.turismo.rs.govbr for information about tourist attractions in Rio Grande do Sul.

1 Almanaque Abril: Brasil 2003, pp. 349, 404-405 (São Paulo: Editora Abril, S.A., 2003). 


\section{PotoAlegre}

Porto Alegre is the capital of Rio Grande do Sul and the seventh-largest city in Brazil, with a population of 1.4 million. ${ }^{2}$ The entire metro area, consisting of twenty-two municipalities, encompasses about owice that many inhabitants, giving Porto Alegre the fourth-largest metro area in Brazil, behind São Paulo, Rio, and Belo Hotizonte, but ahead of Recife, Salvador, Fortaleza, and Brasilia. ${ }^{3}$

Porto Alegre is a relatively confortable city with every modern amenity that can reasonably be expected, such as good public transportation, goodsanitation, banks and ATMs, good hotels, excellent restaurants, and spacious shoppingmalls. Ninety-seven petcent of ponto-alegrenses are literate, ninety-nine percent of homes have access to treated water, and eighty-five percent of homes are connected to closed sewersystems. ${ }^{4}$

The following are Porto Alegre Turismo offices in the city:

Mercado do Bom Fin

Loja 12, Parque Farroupilha

Tel. (51)3388-7669

Salgado Filho International Ainport

Av. Severo Dulitus, 90010-_São João

Tel. (51) $3358-2047$

\section{Mercado Público Central}

Largo Glênio Percs, $s n^{\circ}$-Centro

Centro Cultural Usina do Gasômetro

Avv Pres. João Goulart, 551 -Centro

Praia de Belas Shopping

Av. Praia de Belas, 1181

\section{The Federal University of Rio Grande do Sul}

The Federal University of Rio Grande do Sul (www.ufrgs.br/ufrgs) is referred to in gaticho parlance as the "UFRGS," pronounced as if there were no "F" and with a hard "G": [úr-gis]. Ithas four campuses spread out throughout Porto Alegre, the two most important of which being the downtown campus and the Campus do Vale, on the road to the satellite city of Viamão. If you take courses in languages or international relations, you will have to take a thitty-minute bus ride to get there. The law school is located on the downtomncampus.

The history of the UFRGS started with the founding of the School of Phamacy and Chemistry in 1895. In 1934, various schoolswere consolidated to create the University of Porto Alegre, which became the University of Rio Grande do Sul in 1947. In 1950, the university was federalized. ${ }^{5}$

\footnotetext{
2 Noble, John et, al, Lonely Planet Brazil, 5 th ed, p. 385 (Melbourne: Lonely Planet Publications, 2002).

${ }^{3}$ Almanaque, supra note 1, p. 165.

${ }^{4}$ Almanaque, supra note 1. p. 404.

${ }^{5}$ See wmw.ufrgs briufrgs.
} 
The UFRGS is made up of approximately 27,000 students- $-22,000$ undergraduates and 7,000 graduates - making it the largest university in the south of Brazi. ${ }^{6}$ In Porto Alegre there are also located some ten other universities, the most noreworthy of which is the Pontifica Universidade Católica (PUCRS), prominently located on Av Ipiranga

\section{TheUFRGS Schoolof Law (Faculdadede Direito)}

\section{The law school}

TheUFRGSlaw school was founded in 1900, the first of its kind in the Southem Region of Brazil. For the furst ten years of its existence it was housed in a building of the state government; on July 15,1910 Dean Manoel Andre da Rocha inaugurated the law school in the building that still houses it today? Getúlio Vargas, president of Brazil from 1930-1945 and 1951-1954, and joăo Goulart, president from 1961 1964, rank among the lawschool's many illustrious alumni.

The lawschool has approximately 550 srudents in total. Adnission is extremely selective: out of approximately four thousand applicants, the 140 students that score the higheston the vestibular (entrance exam) are admitted into the freshman class each year, divided evenly between evening and daytime turmas (sections). The UFRGS law school is generally considered the best law school in the Southern Region of Brazil, one of the four or five best in the country, and the best for international law.

\section{The law school faculty}

Faculdade in Portuguese means "school." To say "faculty" in terms of the professorial staft, the appropriate tern is conpodocente; "student body," incidentally, is conpo discente. The following are some of the faculty members you should know a little about in advance of antival:

Prof. Claudia Lima Marques. S.j.D. from the University of Heidelberg (1996). LL.M. in International Conflict of Laws and Civil Law from the University of Tübingen. Specialist in European Community Law from the Europa-Institut, University of Saarbücken. Professor of the Department of Public Law and Legal Philosophy. Leader of the CNPq "Mercosur and Consumer Law" research group and coordinator of the "Law and Post-Modenity" PPGD/NFRGS line of research. Specialistinconsumer law, international conflict of laws, and integration law.

Prof. Cezar Saldanha Souza. S.J.D. in Constitutional Law from the University of São Paulo, Head of the Department of Public Law and Legal Philosophy. Leader of the CNPq research group "Supremacy of the State" and its respective PPGDNFRGS line of research Specialist inconsritutional law, New Federalism, history, and legalphilosophy.

Prof. César Santolim. Professor of Cyber Law and Civil Law at UERGS. LL.M. in Civil Law from UFRGS. Pursuing S.J.D in Intenarional Law from UFRGS (2000-03). Specialist in electronic trade, new technologies, cyber law, and consumer law.

Prof. Tupinambá Pinto de Azevedo. Professor of Environmental Law at the UFRGS Law School. LL.M. from UFRGS. Associate Justice of the Tribunal de Justiça of Rio Grande do Sul. Specialistincriminal law. CNPqresearcher.

\footnotetext{
${ }^{6}$ See pamphlet: UFRGS: Universidade viva.

7 See pamphlet: UFRGS; O patrimonio histórico e de todos nos!

\& See pamphlet: UFRGS em números.
} 
- Prof. Rozângela Motiska Bertolo. Substitute Professor in the Department of Public Law and Legal Philosophy atUFRGS, Professor of Environmental Law in the Escola Superior do Ministério Público of Rio Grande do Sul and in the Escola Superior de Advocacia Municipal. LL.M. from UFRGS. Pursuing S.J.D. atUFRGS (2000-03).

Prof. Pedro Henrique Poli de Figueiredo. Professor of Administrative Law at the Pontifica Universidade Católica (PUCRS), in the EscolaSuperior do Ministério Público of Rio Grande do Sul, and in the Escola Superior de Advocacia Municipal. LL.M. from UFRGS. Pursuing LL.D. at UFRGS (2001-04). Rio Grande do Sul State Attomey.

\section{To Take Care of Before Arrival in Porto Alegre}

\section{Language}

Youshould definitely plan on spending a few weeks in Brazil before classes begin ifyour Portuguese still needs some work; while most of the UFRGS law school professors speak cleaty inclass, some of them are hard to understand, and the rooms in the law school don't have the best acoustics. I can't stress enough the importance of being reasonably fluent before you start classes, and knowledge of Spanish, while certainly helpful, is not sufficient. The pedagogical style in Brazilian law school is very lectureintensive and almost completely non-Socratic; the information that will be nost important for doing well on exans is uttered orally by the professor during class, and readings are only partially enlightening. Btinging a tape recorder to tape class lectures may be a goodidea; borrowing the notes of a classmate in whose academic competence you trust is another partial solution.

One Portuguese language school that I can recommend for study before law classes begin in Porto Alegre is FirstStep Brazil (www,firstrepbrazil.com, info@firststeptrazil.com), which has locations in Ro de Janeiro (Ipanema) and Flonianópolis; the contact person's name, as of August 2003, was Duffy. The Flonianópolis location is a six-hour bus ride fiom Porto Alege. For other language school options you can check out www.studenturniverse com and www.Go Abroad.com.

Additionally, the UFRGS Instituto de Letras offers Portuguese for Foreigners in the regular semester; you have the option of taking Portuguese class concurrently with law classes. If this option appeals to you, contactProfessor Margarete Schlatter (3316-6708, margasch@pro.via-rs.com.br) after you artive in Porto Alegre.

If you feel confident in your Portuguese-speaking abilities and want official certification of your level of proficiency, the Brazilian Ministry of Education offers a two-day test two tines a year, in April and October, for the reception of the Certificado de Proficiência em Lingua Portuguesa para Estrangeiros (CELPE-Bras). TheCELPE-Bras is the Brazilian analogue to the TOEFL. It's the only Bratian-issued certificate of Portuguese proficiency officially recognized by the Braziliangovernment, intentraionally it is accepted in companies and teaching institutions as proof of competence in the Portuguese language, and some Brazilian universities (butnotUFRGS) require itforentry into graduate programs. More information is allegedly located on the Ministry of Education's website, wwwmec govbr, but the site is extremely hard to navigate. Your best option is to ask Margarere Schlatter about the exam after you arrive in Porto Alegne.

Gettinghealth insurance that's good abroad 
The following goes without saying: make sure your health insurance policy applies abroad before you leave the U.S. If it doesn't, change companies or policies to get one that is. Policies from the Dallas-based Mega Life and Health Insurance Company (PO. Box809025, Dallas, TX 75380-9025, tel. 800-767-0700), which supplies all student policies for the University of Texas at Austin, apply abroad.

You'll probably also want to buy the International Student Identity Card (ISIC) from Council Travel (800-2-COUNCL) before leaving the U.S. You'llneedit to be able to purchase student airfare from STA (more details below), and you can get some discounts on museums, etc. (although such discounts with the ISIC are few and far between in Latin America). It also includes one other important feature that you might not personally care about but that your parents will appreciate: repatriation of remains insurance. That way, if youtre fatally hit by astray bullet from the Morro do Pavão (one of the favelas that overlook Copacabana) while strolling along the beach in Rio, Council will pay to getyour body sent back home, something which normally costs in the thousands of dollars. The ISIC is a tittle more than U.S\$20.

Getting your letter of acceptance and your student visa

Out of reciprocity for the visa requirement that the U.S. imposes on all Brazilian visitors, Brazil, unlike its South American neighbors, requires visas of all Americans, even tourists.

Even though it's slighty more expensive and requires the sending of a considerable amount of documentation to the Brazilian consulate, you should get astudentvisa instead of a tourist visa. For one, tourist visas are only valid for ninety days and you would have to leave the country and teenter or obtain an extension in order to stay longer: Futhermore, astudent visagives you certain benefits that a tourist visa does not: (1) it's technically required by law since you are studying at a Brazilian institution; and (2) you will be classified as a resident of Btazil and issued a Btazilian ID (conteirade identutade), which can substitute for your passpont in most circumstances. As a Brazilian resident you have the freedom to leave and enter the country at will and at no expense, and you have other privileges such as the ability to open a bank account.

You mustenter Brazil the first time witlin ninety days of the issuance of your student visa, and from that initial date of entry the visa is valid for one year. The student visa for graduate and postgraduate students is called VTremIV in Brazilian Immigration Department jargon.

\section{Getting your letter of acceptance from UFRGS}

Relaçõe Instiucionaise Internacionais

Av. Paulo Gama $110-6$ andar

CEP90040-060

Porto Alegre, RS

Tel. (51)3316-3902

Fax (51)3316-3973

E-mail: relinter@uffgs.br

Director: Silvia Rocha

Assistant: Rosemeti Antunes 
The first tequired documentyou should work ongetting is a letter of acceptance from UFRGS. The Departamento de Relaçōes Instiucionaise Intemacionais (relinter@ufrgs.br; hereinafter Relaçóes Intemacionais), headed by Sívia Rocha, issues the letter: The Brazilian Consulate requires for purposes of getting the student visa that the letter be "notarized," which means that it must come onspecial paper that says "Serviço Público Federal" on the letterhead. The lettermust be the original; the Consulate will not accept a fax or an e-mail attachment. Silvia Rocha (relinter@ufrgs.br or silviamr@ufrgs,br)will express mail you the letter:

But before Relações Internacionais can issue the letter of acceptance, you must send them certain documents, which can be sent by fax ((55) (51)3316-3973)); a list of those documents follows. Keep these documents and take them to Brazil with you. You will need them later in order to get officially registered as a visiting student. This is an important note of caution: the initial letter from Relaçöes Intemacionais does notregister you in the UFRGS system.

1. A letter, written in Portuguese, fromyou to Silvia Rocha expressing: (a) your incention to study at the UFRGS law school under astudent exchange program; (b) the semester or semesters during which you will by studying at UFRGS' (c) the approximate date on which you will be retuming to the United States; (d) that the exchange will be through the FIPSE/CAPES progran; and (e) a list of courses that you plan on taking. ${ }^{10}$ This list of courses by no means binds you to registering for those particular courses when you artive in Porto Alegre. Make sure you indicate to Silvia where to send the letter and what kind of time constraints you're under with the consulate. It's best to have Silvia send the letter toyou, place it together with the other documentation you have to send to the consulate, and send it all in the same package.

\section{A photocopy of the first pages of your passport.}

3. A recent official transcript (atestado de matricula) from your home institution along with a certified Portuguese translation. ${ }^{11}$

4. A letter from your home instiurion, along with a certified Portuguese translation of the same, declaring: (a) that you are officiallyenrolled as a full-time student; and (b) that you have completed at least forty percent of your degree program.

My suggestion is that you start this process with S1lvia Rocha eight weeks before your planned arrival in Brazil. It will take about two weeks to get the hard copy of the letter of acceptance in your hands, which, granted that you have all the other required documentation already in order, leaves six weeks for the consulate to receive your packet of materials, issue your visa, and mail your passport back to you with the big stamp in it.

\footnotetext{
${ }^{9}$ If you plan on arriving in Brazil before the beginning of the semester (e.g. you arrive in Brazil in January and do an internship in Brasilia until the semester begins in Porto Alegre in March), inform Silvia; she will write the letter stating that you will be studying for the entire period, so that your visa will be valid from the date you arrive in Brazil. Otherwise, you would have to pay another heap of money to get a tourist visa for those initial weeks you'l be in Brazil.

${ }^{10}$ See "Registering for Classes" below for the procedure for choosing courses.

11 Approval of the translation by a Portuguese professor is sufficient certification of the transiation.
} 
Gettingyourstudent visa from the Brazilian consulate

Asstated, along with the letter of acceptance you'l need several other documents to complete the package to send to the consulate. Keep in mind that these requirements, especially che prices, are subject to change, and you should always consult the consulate's welsite to double-check before sending anything off. Additionally, a couple of these requirements I only found out about by calling the consulate on the phone, which means that the list on the website is incomplete and/or the exact requirements change from consulate to consulate.

1. Original, notarized letter of acceptance from UFRGS.

2. A letter from your home institution attesting to your status as a regular student and its approval of your decision to study abroad. (This requirement does not appear on the list on the website.)

3. Passport with at least six months' validity and at least one fully blank page.

4. Two recent 2" X 2" passport-type photos, in color or black and white, front view, full face, light background (snapshots are not accepted).

5. Proof of residence within the consular jurisdiction for the past twelve months. You can only apply to the Brazilian consulate which has jurisdiction over your state of residence; see the list below to figure out what consular jurisdiction you live in. I fulfilled this requirement by sending in a notarized copy of my Texas driver's license. It's best to call the consulate to make sure this is OK.

6. Proof of financial ability to pay for your stay in Brazil This can be a notarized letter from your bank, a copy of a recent bank statement, or similar documentation.

7. For a stay of longer than ninety days, two copies of a recent non-criminal record certificate issued by the Police Department of your place of residence. For me, this was a copy of my blank criminal record from the Texas State Police, complete with fingerprints.

8. A yellow fever vaccination certificate if you've traveled within the last ninety days to any of the following countries: Angola, Bolivia, Benin, Cameroon, Colombia, Ecuador, Gabon, Ghana, Gambia, Guinea, Liberia, Nigeria, Peru, Sierra Leone, Sudan or Zaire. Note that if you visit Brazil's neighbors Bolivia, Colombia, Ecuador, and/or Peru during your trip to South America and then return to Brazil, you're technically required to have a yellow fever certificate. ${ }^{12}$

9. A postal money order for $\$ 170$ (or $\$ 160$ if you hand-deliver the materials). The $\$ 170$ figure includes the following fees:

12 When I returned to Brazil from a trip to Peru, the immigration official checked my yellow fever certificate. 
- Visa fee payment: $\$ 40$.

- Reciprocity fee: $\$ 100$. Blame the US. government for this one.

- Handling fee for applications sent by mail: $\$ 10$.

- Bradian Federal Police processingfee: \$20. Thisrequirement does not appear in the liston the website. You'll have to pay an additional $\$ 30$ or so when you get to Brazil and register yourpresence with the Federal Police; trying to claim to the Porto Alegre Federal Police that I had already paid $\$ 20$ of that fee proved futile forme.

The following is a list of Brazilian consular jurisdictions in the United States. Remember that you can only apply to the consulate in whose juisdiction you reside.

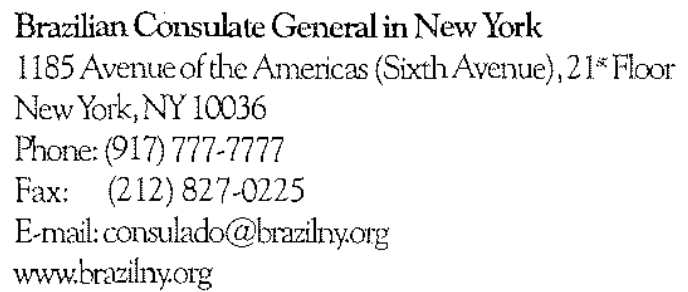

Jurisdiction: States of Connecticut, Delaware, New Jersey, New York, Pennsylvania and the Bermuda Islands.

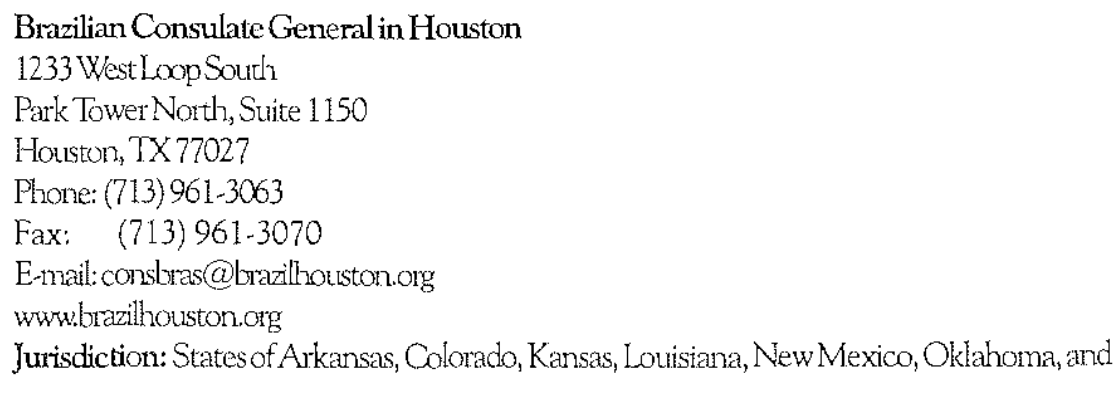

\section{Brazilian Consulate General in Boston}

The Stattler Building

20 Park Plaza, suite 810

Baston, MA02116

Phone: (617) 542-4000

Fax: (617) 542-4318

E-mail:cgtos@ma.ultranet.com

www.consulatebrazil.org

Jurisdiction: States of Maine, Massachusetts, New Hampshire, Rhode Island and Vermont. 


\author{
Brazilian Consulate General in Chicago \\ 401 North Michigan Avenue, Suite 3050 \\ Chicago, IL 60611 \\ Phone: (312) 464-0244 \\ Fax: (312) $464-0299$ \\ E-mail:bras-cg@ix.netcom.com
}

Jurisdiction: States of Tlinois, Indiana, lowa, Michigan, Minnesota, Missouri, Nebraska, North Dakota, South Dakota, and Wisconsin.

\title{
Brazilian Consulate General in Los Angeles \\ 8484Wilshire Blvd, suites 730-711 \\ BeverlyHills, CA90211 \\ Phone: (323) 651-2664 \\ Fax: (323) 651.1274 \\ Email.consbrasla@eathlinknet
}

Jurisdiction: States of Arizona, Hawaii, Idaho, Montana, Nevada, Utah, Wyoming, and in California, the counties of Imperial, Kern, Los Angeles, Orange, Riverside, San Bernardino, San Diego, San Luis Obispo, Santa Barbara, and Ventura.

\section{Brazilian Consulate General in Miami}

2601S. Bayshore Drive, Suite 800

Miami,FL 33133

Phone: (305) $285-6200$

Fax: (305) $285-6229$

E-mail:consbras@brazilmiamiong

wwwbrazimianiorg

Jurisdiction: States of Alabana, Florida, Georgia, Mississippi, North Carolina, South Carolina, and Tennessee. Puerto Rico, US Virgin Islands, and the Commonwealth of the Bahamas.

\author{
Brazilian Consulate General in San Francisco \\ 300 MontgomeryStreet, stute 900 \\ San Francisco, CA, 94104 \\ Phone: (415) $981-8170$ \\ Fax: (415) $981-3628$ \\ E-mail:consular@bazilsforg \\ wwwbrazilsf.org
}

Jurisdiction: States of Oregon, Washington, Alaska and in the state of California, the counties of Alameda, Alpine, Amador, Butte, Calaveras, Colusa, Contra Costa, Del Norte, El Dorado, Fresno, Glenn, Humboldt, Inyo, Kings, Lake, Lassen, Madera, Marin, Mariposa, Mendocino, Merced, Modoc, Mono, Monterey, Napa, Nevada, Placer; Plumas, Sacramento, San Benedito, San Francisco, San Joaquin, San Mateo, Santa Clara, Santa Cruz, Shasta, Sierra, Siskyou, Solano, Sonoma, Stanislaus, Sutter, Tehama, Trinity, Tulare, Tuolumne, Yolo, and Yuba. 
Brazilian Embassy in Washington, D.C.

3006 Massachusetts AvenueN.W.

Washington, D.C. 20008

Phone: (202) 745-2837

Fax: (202) $745-2827$

www.brasilemb.org

Jurisdiction: District of Columbia, states of Kentucky, Maryland, Ohio, Virginia, and West Virginia.

Air Passage to Brazil

See "Air Travel to Brazil" under "Practical Matters for Living in Brazil and Porto Alegre" below.

III. To Take Care of Soon After Arrival in Porto Alegre

Registering with the Brazilian Federal Police

Within thirty days after arrival in Brazil, you have to go in person to the local office of the Polícia Federal and register your presence in the country. Do not fail to do this; they take it very seriously. If you are in Porto Alegre during that initial thirty-day period, Relações Internacionais will arrange for a car to take you and wait for you while you get registered. If you decide to go on your own, here are the address and phone of the Porto Alegre Policia Federal; directions on what bus to take appear below.

Departamento de Polícia Federal

Superintendência Regional no Rio Grande do Sul

Delegacia de Polícia Marítima Aeroportuáriae de Fronteiras

Grupo de Registrode Estrangeiro

Av. França, 96 esq. Paraná 92

CEP9040-600 Porto Alegre/RS

Tels. (Registrode Estrangeiro): 3358-9070,3358-9071

Tel. (general): $3359-9000$

Contactperson: Pírez

You'll have to take with you the following items:

1. Your passport and a photocopy of the picture page and every page with a stamp on it. The Federal Police needs a full blank page on which to place a page-sized stamp.

2. The entry card you filled out on the airplane on the way to Brazil that the immigration official stamped when he stamped your passport. If you've lost it, begging the Federal Police for mercy is not likely to help matters. 


\section{Two passport-sized photos. ${ }^{13}$}

4. The documentation sent back to you by the consulare (a receipt of payment from the consulate, the original letter of acceptance, and the second copy of your criminal record).

5. Your address, complete with CEP (zip code), and telephone number for purposes of filling in the corresponding blanks on the forms.

\section{Approximately $\mathrm{R} \$ 100$ for the processing fee,}

7. I's probably best to take with you all the documentation that you faxed to Retações Internacionais, just in case the Police want to see something from it.

You'll have to fill out a form or two, sign some things, and get your fingerprints (impresxóes digitais) taken. They will issue you an unlaminated provisional identification card (referred to as your "protocolo") with your picture and a 17-digit protocol number on it; this card is extremely important. It takes at least three months for them to make your permanent ID card (i.e., the non-provisional carteira de identidade), so depending on how long you're staying in Brazil, you might not ever lay eyes on it. ${ }^{14}$ You'll have to start calling the Policia Federal around three months after your initial visit to find out if the card is ready, and if it is you'll have to go there in person to pick it up. You must have one of these two $\mathrm{IDs}$, the provisional protocolo or the permanent carteira de identidade, with you every time you enter or leave Brazil; if you lose it or forget it at home the fine is quite stiff. Note also that the protocolo expires after 120 days; if after 120 days your carteira de identidade is still not ready, and you plan on leaving and reentering Brazil, you must first go to the Polícia Federal to get an extension (promrogaçâdo) on your protocolo. Luckily, the protocolo is made on the spot while you wait.

If you get really impatient about the fact that it is taking months and months for yourcarteira de identidade to artive, and the Policia Federal seems to be giving you the runaround every time you call them to ask the card's status, you can call the place in Brasilia that actually makes the cards and ask then what's taking so long: (21)311-0384 (note that phone numbers in somecities, such as Brasilia, are only seven digits).

Also beware that the federal Police maysend you aletter subsequent to your initial visitsummoning you to appear in person with certain documentation, most likely something they forgot to request a photocopy of the first time you went there. You'll also have to return there in person to pick up the permanentID Relaçöes Internacionais is not likely to arrange for a car to take you on these subsequent visits, so you'll have to go on your own. Bus 653 leaves from Praça Rui Barbosa downtown and about twenty minutes later passes down Av. Brasilone block away from the Federal Police; ask the driver to tell you where to get off. To get to Praça Rui Barbosa from the law school, walk up Av. João Pessoa and pass

\footnotetext{
;3 You can get passport photos made at several photo shops throughout Porto Alegre; there seems to be one on every block downtown. My suggestion is that you get several made and leave them in your wallet; you'll need them for various IDs you'll eventualiy have to get made.

${ }^{14}$ I was in Brazil for a total of seven months, and when 1 left my carteira still wasn't ready.
} 
under the overpass (viaduto); curve around with the street, and the first intersection you come to is Av. Di Flores. Turn right on Dr. Flores, walk down the hill a few blocks (passing McDonald's, the Rua dos Andradas, and several ocher streets), and Praça Rui Barbosa is at the end.

\section{Getting a CPF (social-securityntunber)}

The Cadastro de Pessoa Física $(\mathrm{CPF})$ number in Brazil is the analogue to the social-security number in the U.S. You have to have one if you want to open a bank account in Brazil, get a Brazilian creditcard, buy a plane ticket online, or receive any sort of payment from UFRGS (such as, for example, reimbursement for travel expenses for a law conference you worked at on behalf of Professor Claudia). I strongly suggest that you go ahead and get $\mathrm{CPF}$ number soon after your arrival in Porto Alegre-it will make your life a whole lot easier:

The process istelativelyeasy, with the exception of the document that states your parents' names. Before going anywhere, you need to compile the following five items:

\section{Your passport, and a photocopy of the whole thing.}

2. Some sort of proof of residence. This can be an electricity bill with your name on it, a letter from your apartmentmanager, or a letter attesting to your residence in Brazil from Silvia Rocha in Relaçöes Intenacionais.

3. An official document, in Portuguese, with both your parents' full names. This is the most difficult item to get. One thing you can do is translate your bith certificate while still in the U.S. and send the original and the translation to the Brazilian consulate to get the translation officially certified. A certification from a university professor would probably also suffice; just make sure there are plenty of official-lookingstamps on the document. You could also take your birth certificate to a translator in Porto Alegre; the fee he'll charge is something like R $\$ 15$ per page.

4. The letter of acceptance that Sívia Rocha sent to you, which you should have gotten back from the Consulate when they sent you yourpassport with the visa stamp in it. If you don'thave it, just ask Silvia to print you out another one. It's probably a goodidea to take along a photocopy of this letter as well.

\section{Cash in the amount of $\$ 4.50$.}

With these five items in hand, go to any teller at any Banco do Brasil and tell her that you want to deposit the R $\$ 4.50$ fee for getting a CPF Shell look over your documents and, hopefully, deposit the R \$4.50 into the Receita Federal's (the Brazilian Intemal Revenue Service) bank account. She"ll then give you the documents back with a receipt of deposit.

You need to wait at least 24 hours for the deposit to process. Then take all those documents, complete with the bank receipt, to the Receita Federal at Avenida Jasé Loureiro da Silva 445 in the Cidade Baixa bairro. The attendant at the Receita Federal should give you your CPF number on the spot; an official document with yourCPFon it will take another month or so to process, but luckily theyll 
mail to you. Ifyou have any questions about this process, you cancall the Receita Federal at $3214-2000$ or the Plantão Fiscal (the subdivision of the Receita Federal that deals with CPF issues) at 3216-0146.

Registering forclasses (matricula)

For exchange students, registering for classes isn't the easiest thingin the world, and it requires a considerable amount of patience. Below thave tried to present astep-by-step procedure to follow.

Checking on what classes are offered and viewing their descriptions

Looking over the list of what classes are offered and seeing their descriptions is relativelyeasy, and it's something you can do over the intentet before you arrive in Porto Alegre.

A linguistic note is in order at this point. In the Portuguese of Rio Grande do Sul (but not in the Portuguese of all parts of Brazil, such as Rio), to say "class" in the sense of a semester-long course such as "Comparative Law" or "Civil Law II", the word is cadeira, the same word as that used for "chair" (piece of furniture); another word for "class" in this sense is disciplina. Curso is "major"; when someone asks you what curso you'te in, the answer would be direito, "law". Auld is the word for "class" in the general, everyday sense (e.g., tenho cula hoje à noite, "I have class tonight"). Classe means class in the sense of "Category" as in classe scxial" "social class."

Each year, the UFRGS law school admits the 140 students into its freshman class thatscore the higheston the vestibular entrance exam. Each of the five years has two tumas, a daytime tuma and an eveningtuma. All basic, required classes such as Crininal Law or Civil Law are offered in both moning andevening schedules. Electives such as Comparative Law or Spons Law integrate students from both daytime and evening sections and may be offered at any time of the day or evening. As an exchange student, you have the freedom to take any class that you want in any year and in the daytime or evening; taking lasses in several differentyears is a good way to get to know more people in the school and broaden your friend base.

To get a list of classes for a given semester, do the following:

\section{Co towwwdireito.ufigs.br:}

2. Cickon "Horáriose Vagras" under the heading "Informaçôes Acadêmicas" in the left-hand column.

3. On the drop-down menu, click on "DIR-CIÊNCIASJURÍDICASESOCIAISDIURNO" for the daytime class schedule or "JUR-CIENCLASJURIDICASESOCIAISNOTURNO" for the eveningclass schedule.

4. Below the drop-down menu, elick on the semester for which you wish to view the schedule. Each year has two semesters. 20031, for example, is the firstsemester of 2003 (Marchor April through July or August) and 20032 is the second semester of 2003 (September through December). You canconsult anypastsemester (PASSADO) back to 19942, the present semester (PRESENTE), or the nextsemester But keep in mind that the schedule for the next semester is not posted until a few weeks before the 
beginning of that semester: In the meancime, agood way to get an idea of the classes that should be offered in any given semester is to check the contesponding semester from the year before.

5. Cick on "Consultar".

6 Agrid shouldappear with seven columns. Asample appears below.

\begin{tabular}{|c|c|c|c|c|c|c|}
\hline Código & Denominação da Disciplina & $\mathrm{CH}$ & Turma & $\begin{array}{c}\text { Horário-Sala } \\
\text { Prédio }\end{array}$ & $\begin{array}{l}\text { Vagas } \\
\text { Ofer } \\
\left(^{*}\right)\end{array}$ & $\begin{array}{c}\text { Viag as } \\
\text { Ocup } \\
(* *)\end{array}$ \\
\hline DIR0101 & CRIMINOLOGIAI & 2 & A & $6072-0005-11108$ & 70 & 0 \\
\hline \multirow[t]{2}{*}{ DRR0103 } & $\begin{array}{c}\text { DIRETTO PROCESSUAL PENAL I- } \\
\text { A }\end{array}$ & 4 & A & $2072-0001-11108$ & 70 & 0 \\
\hline & & & & $3092-000 !-11108$ & & \\
\hline DIR0106 & DIRETO PENAL ESPECIAL -A & 4 & U & $51140009-11108$ & 15 & 0 \\
\hline DIR0107 & DIRETTO EXECECOES PENAIS-A & 4 & $\overline{\mathrm{U}}$ & $61340005-11108$ & 70 & 0 \\
\hline
\end{tabular}

To see a description of a class in which you're interested, do the following:

1. Return towwwdireito.ufrgs,br:

2. Click "Dados Sobre Disciplinas" under "Informaçôes Acadêmicas".

3. Put in the code (cótigo) of the class whose description you want to see. Using Criminology Ias an example, put in DIR01001. Click "Consultar".

4. ApagewithDIR01001-CRIMINOLOGIAInadrop-down window should appeat: Click "Consultar" again and the following description should appear.

\section{Disciplina: \\ DIRO1001-CRIMINOLOGIAI \\ Carga Horária: 2 horas/aula \\ Nome Completo: CRIMINOLOGIAI}

Súmula: História da Criminologia. Divisóes da Criminologia. Conteúdos e limites do objeto da Criminologia e suas relaçốes com as demais Ciências Criminais. Importância da Criminologia. Funçöese Perspectivas da Criminologia. Ocrime como fato jurídicoe como fato social. Divergências. As principais teonias sobre a criminalidade. As várias técnicas e métodos da Crininologia. A reincidência ea periculosidade. A consolidação da Criminologia como Ciência. As escolas criminológicas. A nova Criminologia. A sociedade criminogênica. 
Pré-Requisitos:

Nãohápré-requisitos

\section{Cursos Vinculados: 158-00.CIENCIASJURIDICASESOCIAIS-NOTURNO 260-00-CIENCIASJURIDICASESOCIAIS-DIURNO}

Asyoucan see, Criminology I meets two hoursper week and has no prerequisites. Buteven if it did have prerequisites, as an exchange student you probably could take it anyway; on this issue for a particular class consult Professor Claudia.

The professor's name doesn't appear anywhere in the semester course list or in the course descriptions, and this is one of those things that are a little more difficult toget information about. Your best bet on this issue is to consult Professor Claudia or the UFRGS student that is assigned to help you.

Figuring out your class schedule and where each class meets

Official registration (matricula) for exchange students doesn't take place until a couple of weeks after classes begin. Youll have to figure out a workable schedule and start going to classes before being officially registered.

Each semester the law school publishes aneasier-to-read grid schedule with the hours and days broken out and each class listed in its day and time. The daytime and evening sections have their own grids, and eachyear has its own page. The schedule is only avallable in hard-copy form at the beginning of the semester; you can pick it up in the law school photocopy toom ("o Xérox," accessible from outside the building right beside the snack bar or from a window just to the right after entering the UN Library).

Until you can get your hands on this schedule, however, you'll have to use the one from the website, the sample of which is printed above. For a full load, you need to take somewhere around eighteen credit hours (for more details on what is considered a full load, see next section). The third column indicates how many credit hours ("CH") each class is worth, either two, four, or six.

The first number in the fifth column indicates the day and time (horánio) that the class meets. The first digit of the four-digit number is the day; 2 is segunda-feira (Monday), 3 is tercafeira (Tuesday), 4 is quarta-feira (Wednesday), 5 is quinta-feira (Thursday), 6 is sexta-feira (Friday), and 6 is sábado (Saturday). Add thirty minutes to the combined second and third digits to get the time. For example, if the second and third digits are 07, the class starts at 7:30am; if they are 14 , the class starts at $2: 30 \mathrm{pm}$. The fourth digit indicates how many hours long the class is on that particular day. Thus, if the first number in the fifth column is 5072, the class meets on Thursday from 7:30 to 9:30am.

The second number in the fifth column indicates the room in which the class meets. Thus, if the second number in the fifth column is 0009 , the class meets in room 9. The third number in the fifth column, the building in which the class meets, is always 11108, the code number for the law school building.

You probably don't have to worry about the information in the sixth and seventh columns, vagas oferecidas (seats offered) and vagas ocupadas (seats filled); even if the class is filled, as an exchange student you can likely get into it if you want it. 


\section{What is considered a "full load"}

As mentioned above, a full load is somewhere between eighteen and twenty-two credit hours, composed of any combination of 2-hour and 4-hour classes. This number of hours of class per week sounds impossibly high by U.S. standards, but don't worry: you never actually end up spending that many hours in class. Most classes, iu practice, will end up starting after the official start time or ending before the official end time. A notable exception is any class taught by Prof. Cezar Saldanha, which will start on time and go the full two hours. To get a rough estimate of how many hours per week you'll actually be sitting in class, divide the number of credit hours you're officially talking by two and add an hour or so.

\section{Suggestions on which classes and professors to take}

The decision on whatclasses to take is largely apersonal one, although Professor Claudia will have some suggestions for you that should be given considerable weight in your decisionmaking process. ${ }^{5}$ You should ty to pick the classes that fit best in to your area of legal interest or that will helpyou understand the Brazilian legal system and its differences from the U.S. legal system in a more general way. The best way to think aboutclasses is to divide them into two groups: dasses on Brazilian law and classes that dorit focus exclusively on Brazilian law. Perhaps the best strategy is to take a few classes from both categories.

- Classes on Brazilian law Try to avoid advanced classes focusing exclusively on Brazilian law; even if you understand every word of Portuguese uttered by the professor, you won't be able to understand the material because you lack the prenequisites. A good rule of thumb regarding classes on Brazilian law that have various levels (e.g., Direito Comercial I, Direito Comercial II, etc.) is to take the low-level class with the second-or third-year students, instead of the high-level class with the fifth-year students. For example, instead of taking Direito Penal Especial with Professor Tupinambá Azevedo, which is a fifth-year class focusing on advanced aspects of Brazilian criminal law such as white-collar crime and money laundering, take Direito Penal II with the same professor; that way, you'll still get good exposure to Brazilian criminal law and the opportunity to take a criminal haw class with Tupinambá, but you'll also be able to keep up with what's going on. This rule of thumb does not apply to fourth-or fifth-year classes on Brazilian law that aren't part of a sequence, such as Direito Ecológico; you should be able to understand these classes without excessive difficulty.

Classesnotexchusivety on Braxilian law. Induded in this category are classes suchas Direito Comparado, Diteito das Relaçōes Internacionais, Direito Internacional Público, Direito Internacional Privado, Política e Teoria do Estado and Direito dos Direitos Humanos. Even as a non-Brazilian, you shouldn't have any particular difficulty understanding these classes; you're in the same boat as all the other students. If you haven'talready taken Comparative Law in the U.S, you should take it at UFRGS; it's very helpful in understanding the differences between common-law and civil-law systems. "Private Intemational Law" is the civil-taw term for what we in the U.S. call "Conflict of Laws," and thas two parts:

\footnotetext{
${ }^{5}$ Keep in mind that everything you do has to be approved, in the first instance, by Professor Claudia; this essential rule applies with special vigor to your decision on what classes to take.
} 
Direito Internacional Pivado I and II. Unless you have taken Conflict of Laws in the U.S., make sure you take DIP I before taking (or concurtendly with) DIPII.

But more important than the subjects of the classes you take are the professors that teach them. The quality of your learning experience at the UFRGS law school will depend mostly on the quality of your professors, so choose your classes with the professor as the central criterion. First and foremost, you must be able to understand the professor, even if he's the best professor at UFRGS, if you can't understand his Portuguese then you'll get nothing out of the class. During the first week of classes you should test the waters by attending as many classes as you can, to figure out which professors you can understand.

Otherwise, taik to UFRGS law students and Professor Claudia for suggestions on whichprofessors are the bestones for you. Ill suggest a few here that are excellent professors and that speak clearly: Claudia Lima Marques, Cezar Saldanla SouzaJt, Véra Maria Jacobde Fradera, Tupinambá Azevedo, and Pínio Melgaré. Unfortunately, there were some reputedly verygood professors-whose names I won'tmention here-who either spoke toorapidly, too inaudibly, or too mumbly for me to be able to take their classes.

\section{Getting officially registered}

Despite your already having been accepted as an exchange student at UFRGS and received letter verifying such acceptance, when you arrive in Porto Alegre your name is not yet present in the UFRGS system. The process of registering for classes is the same process that gets you officially cadastrado with the Centro de Processamento de Dados (CPD, tel. 3316 5333) as a visiting student at UFRGS, and only from the point at which you receive a registration number (nimero de matricula) will you be able to enjoy certain privileges, described below.

Getting registered for classes is an unduly bureaucratic process reminiscent of the process you had to go through to get your student visa. Luckily, most of the materials you needed to get your letter of acceptance and your visa can be reused in getting registered. It is imperative that you bring the following materials with you to Brazil ${ }^{16}$ :

1. Histórico Escolar Original. This is an original copy of your official transcript with an authenticated taanslation into Portuguese.

2. Atestado de Matricula. This is a letter from your school's student affairs office to the UFRGS.

The following is a sample in English: "This is to certify that $X$ is a full-time student at Pace University School of Law. He is curnently entolled in fifteen (15) credit hours for the Fall Semester, 2003, which extends from August 27 to December 19, 2003. I also certify that X matriculated in Pace University School of Law on August 29, 2001."

Also bring an authenticated translation of the letter into Portuguese which, if the sample above is followed verbatim, should read like the following: "Certifico que X é estudante ${ }_{16}$ These requirements are set forth in UFRGS Resolução No $33 / 2000$. 
em tempo integral na Faculdade de Direito da Pace University. Atualmente está matriculado para ganhar quinze (15) horas de crédito no semestre de outono de 2003, que começou no dia 27 de agosto e se estenderá até 19 de dezembro de 2003. Também certifico que X se matriculou na Faculdade de Direito da Pace University em 29 de agosto de 2001."

3. Passaporteou Certidão de Nascimento-cópia That is, a photocopy of your passport. Make sure the image of your face is clear.

4. Conteúdo Programático ou Ementas de todas as disciplinas cursadas com aprovação. Conterido programático and ementa are the two words used at UFRGS to refer to what we in the U.S. call "course description." You must therefore bring a list with a description of every course you've taken up to this point in law school. Don't worry about getting a Portuguese translation for this one.

5. Grade Curricular ou Atestado informando ter cumprido um mínimo de $40 \%$ de seu curso na I.ES. This is an officialletter from your home institution stating that you have completed at least forty percent of the coursework required for graduation, with authenticated translation into Portuguese.

You'll also need two more items, obtainable only upon arrival in Porto Alegre:

6 Taxa. At the time of writing in August 2003, it cost R $\$ 29.40$ (around U.S.\$10) to get matriculated. You have to pick up a slip of paper from DECORDI (the Registrar's Office) with the University's bank account number on it, and go in person to the campus Banco do Brasil (near Lanches Antônio) to deposit the registration fee. You'll need to include the bank receipt with these other documents.

7. Proposta de estudos justificada pelo aluno, relacionando a(s) disciplina(s). This is a letter from Professor Claudia listing the classes that you have decided to take and requesting that the appropriate agencies effect your matriculation, in words such as the following: "Requeiro a inscrição e matrícula oficial do aluno $X$ nestas cadeiras, uma vez que necessita comprovar que está regularmente matriculado na UFRGS, na Faculdade de Direito e como aluno regular com carga horária oficial completa."

\section{Departamento de Controle eRegistro Acadêmico-DECORDI}

Av. Paulo Gama, 110--Prédio 12106 Anexo I da Reitoria

90046-900-Porto Alegre-RS-Brasil

Once you have compiled these items, go in person to the Protocol Office (Entidade Protocolizadora) on the UFRGS main campus in the Reitona Annex building, beside Lanches Antonio through a door between the UFRGS bookstore and DECORDI. There you need to iniciar iom processo with them formatriculation, and pick up a card with your protocol number on it.

Then take that card next door to the Departamento de Controle e Registro Acadêmico (OECORDI, the Registrar's Office) and hand them the seven items listed above. Then be patient; your 
file has to bounce between DECORDI and Godonly knows how many other places (including the law school's approvingentity, known as COMGRAD) before it at long last makes its way back wo DECORDI, where itgets final approval. Once your fle is finally approved, DECORDI ptints out a signed and stamped registration sheet (comprovante dematricula) listing your all-important registration number (nimero de matricula) and all the courses in which you're enrolled. You have to keep checking back with DECORDI to find out if your file has been approved. The whole processfrom the time you turn in yourmaterials until the time when you get your numero de matricula will probably take more than a month.

Note that until you receive your mimero de matricula you name will not appear on the roster of any of your classes; you will have to write down your name every day when the professor passes around the attendance sheet, and explain to the professor that you'te doing that because your tegistration is still being processed. Note also that you will not yet be able to get student bus fares, use the University Restaurant, or check out books from any campus library. The inability toenjoy any of these privileges until the process is complete makes being patient noeasy task.

Luckily, youre not left to your own devices in this arduous process. Professor Claudia's assistant Ades Sánchezy Vacas will helpyou compile all the necessary materials, get the process started, and track your file as it makes its way through the various reviewingentities. Her office is on the first floor of the law school just to the left of Room 9; itsays "COMEX" over the doot Her office telephone is 3316.4059

\section{The benefits registration brings}

As mentioned above, when you finally get registered you will have a registration number (número de matricula) that is the key to getting the two student IDs you need in order to take advantage of the benefits of being a UFRGS student. Taking advantage of the following benefits requires one of these two IDs: (1) getting urban bus fare for half price on all days except Sundays; (2) checking out books from the library; and (3) getting super-cheap lunch at the UFRGSRestaurant

\section{Gettingyour two UFRGSstudentIDs}

Once you are officially registered, DECORDI (the Registrar's Office) will give you a signed copy of your registration (comprovante de matricula) along with a registration number (número de matricula). When you (at long last) get this unique number you know your name is officially in the CPD (Centro de Processamento de Dados) database, and you can proceed to get your two IDs processed.

Diretório Central de Estudantes

Prédio da Casa de Estudantes

Av. João Pessoa 41

Tel. (51) 3316.4032

Schedule: Mon, - - Fri, noon-6pm

Requirements for EPTCID:

1. Registration sheet

2. Photo 


\section{3. $\mathrm{R} \$ 5$}

The first ID (cartera or canteimha estudanti) is theUFRGS studentID and it's relatively easy to get. It'scredit-card-sized and blue with a number and bar code; it's what youll need to check out books, getcheap lunch, andidentify yourself as an UFRGS student in general. The ID office is in Anexo II da Reitoria, the same building as the UFRGS Banco do Brasil. Youenter through the door right across from Lanches Antônio and walk down the hall to the right; it's the second door on your right. Take with you the registration sheet that DECORDI gave you and show it to the attendant. He will pull up your record, take your picture, and produce your ID in about three minutes. This ID is free.

The second ID, called the Carteira Escolar, is produced by the City of Porto Alegre Office of Public Transport (Empresa Pública de Transportes e Circulação-EPTC) and is common to all students at all levels throughout the city. It allows you to buy half-price bus tokens. It is larger than acreditcard and green. To getir, take the registration sheet that DECORDI gave you along with a $3 \mathrm{~cm} X 5 \mathrm{~cm}$ photo to the Diretório Central de Estudantes (DCE) in the Prédio da Casa de Estudantes, the hideous red buildingjust across. Av. Joano Pessoa from the law school; you enter through the door just to the right of the Restaurante Universitátio (RU) and go up the wooden stairs to the second foor: Youll have to pay R\$5 for this one, and it takes about ten business days (dias utteis) to process.

Gettinghalf-price bus fare tokens

Empresa Pública de Transportese Circulação

Pasto01-Centro

Av. Alberto Bins 860

Schedule: Mon.-Fri., 9am--5pm

Requirements for bus tokens:

1. Filled-out form with Banrisulcode

2. EPTCID

The day you pick up the green ID from the DCE, they will give you a perforated two-part form produced by the EPTC that you'll need in order to deposit the in-advance month's worth of bus fares into the EPTC's account at BannisuL Bank. Note that this is the only time that DCE will furnish this form; all subsequent times it must be picked up at the EPTCoffice.

You have the option of buying 50 or 75 bus tokens per month. Fifty tokens at the time of writing in August $2003 \operatorname{cost} R \$ 36$, or $R \$ 0.72$ perbus ride (i.e, half the nomal fare). Fill out the EPTC form with the appropriate data (Le., your name, ID number, and how many tokens you want) and take it, along with the necessary amount of cash and your FI'TCID, to any Bantisul brand r; there's a conveniendy located branch a few doors down from the DCE (across the street from the law school). Give the teller the twopartform, the cash, and your EPTCID and she will give you one part of the form back, with a code printed on it provingyoumade the deposit.

You must then take this portion of the form to the EPTC office in order to pick up your tokens (fichas); the downtown office is the mostconvenient. Toget to the downtown office from the lawschool, walk up Rua Sarmiento Leite a few blocks until you reach Av. Independência; cross Independência and walk down the steps to the right of Av. Conceiçäo, the street that passes through the tunnel under 
Independência. The first coner youll come to is Conceição and Av. Alberto Bins. Turn right onto Alberto Bins, and the EPTC office is located albout halfway down the block on the other side of the street. Show them your EPTC ID and give them the form with the Banrisul code on it, and they will give you a bag of tokens. Make sure they also give you a fresh two-part form; you'll need it when you go through the whole process all over again one month later:

A few words of caution: you must try to gauge beforehand how many tokens you thrik you'll need for the comingmonth (i.e., 50 or 75 ), because you're onlyentitled to one package permonth. If you have extra tokens at the end of the month you can of course keep using them in to the following month, but if you run out before the month is over, you'l have to pay regular fare until you'reencitled to buy more tokens (i.e., the first day of any given month). Note also that all Porto Alegre buses, but only buses, accept EPTC tokens; lataçäes do not accept them (one more incentive to avoid lotaçöes whenever possible; see "Public Transportation Within Porto Alegre," under "Practical Matters for Living in Brazil and Porto Alegre," below), and urban buses in other cities in Rio Grande do Sul and Btazil don't accept them. Additionally, even Porto Alegre unban buses donot accept tokens on Sundays and holidays; you'll have topay fill price on those days (except for the last Sunday ofeach month, whenpublic aransportation is free for everyone).

When you board the bus, hand the cobrador (i.e., the money-collectinggry) one token and your EPTCID; hell write your ID number down and hand your ID back to you.

\section{Registering with the law library to be able to check out books}

Checking out books is simple once you have your UFRGS student ID (the blue one). Just take your desired book up to the counter and hand the librarian your ID. Beware that the first time you try this, there may still be some necessary piece of information about you still not registered with DECORDI (e.g., your e-mail address). If there is, you won't be able to check the book out at that time; you'll have to go back to DECORDI and fix whatever's wrong before you can check anything out. See the "Law Library and UN Library" section under "Practical Matters for Living in Brazil and Porto Alegre," below, for more library details.

\section{Getting cheaplunch at the University Restaurant}

The University Restaurant (RU), which is open at lunchtime from Monday to Friday, is right across Av. João Pessoa from the law school in the Prédio da Casa de Estudantes. Lunch is incredibly cheap: at the time of writing in Juky 2003 , it was $\mathrm{R} \$ 1.30$, with $\mathrm{R} \$ 0.30$ for a drink While the restaurant is certairly nothing to write home about and bears some resemblance to a prison cafeteria (e,g, the trays are stainless steel with dangerously sharp edges and the two guys crammed on either side of you give you very little ellow room), the food is OK (and certainly no worse in quality than the hot lunch they serve at Lanches Ferneira (the snack bar at the law school) for a whopping R $\$ 5.90$ ): lettuce, rice, beans, some kind of meat, and jello. And did I mention how cheap it is?

To take advantage of this deal, simply show your UFRGS student ID (the blue one) to the cashier uponentering the RU.

IV. Practical Matters for Living in Brazil and Porto Alegre 
Air travelfrom the U.S. to Brazi

General matters

Due to the volatility of aintine pricing systems and the plethora of different websites and travel agencies selling tickets, the secret to finding a reasonably priced roundrip ticket from the U.S. to Brazil is anyone'sguess. The problem of costliness is compounded when the city of origin or the city of destination, or both, are not international hubs; Porto Alegreand Austinare the twomostrelevantexamples. And the problem is compounded even further when your stay in Brazl exceeds a certain amount of time, such as ninety days; round-rtip tickets for stays of longer than three months always seem to be considerably more expensive.

Asafe bet and agood place to start your seath is STA Travel, which bought out Council Travel not long ago to become the purported largest student travel agency in the word. STA has offices all over the U.S. and in several Brazilian cities, including the followingrelevant locations:

STA.Affiliates in Porto Alegre

- Student Travel Bureau

Rua Quintino Bocaiuva 267

Porto Alegre, RS $90440-051$

Brazil

Tel: 555133462774

Foc 55513465444

- Student Travel Bureau

\section{Rua Anita Garibaldi, 1515 \\ Bela Vista \\ Ponto Alegre, RS 90480-201 \\ Brazil}

Tel: 555133280787

Fax: 555133280787

caren@stbbelavista.com.br

STA Affliate in Rio De Janeiro

- Student Travel Bureau

Rua Visconde de Piraja 550

Sobreloja 201

Ipanema, Rio de Janeiro, RS 22410-002

Brazil

Tel: 55215128577

Fax: 55215114537

STAAffiliate in São Paulo

- Student Travel Bureau

Ave. Brigadeiro Faria Lima 1713 


\section{6 th Floor}

Säo Paulo, SP01452-915

\section{Brazil}

Tel: 551138161500

Fax: 551138166444

STA's website, at www.statravel.com, is of limited usefulness; it's much more productive tocall their 24-hour US. service line at 1-800-777-0112.

Porto Alegre's three-letter airport code is POA. Nevertheless, finding a student fare all the way to Porto Alegre will likely be impossible; student fares will probably only be avaliable to Rio de Janeiro (Galeão-GIG) andSão Paub (Guaruhos-GRH), and the rest of the trip will be aregular fare. Aroundtrip tlight from Rio or São Paulo to Porto Alegre is about U.S.\$200.

Airlines that fly between the U.S. and Brazil

\section{- Continental Airlines}

In the U.S.

www.continental.com

U.S. toll-free: 1-800-231.0856

In Brazil

Brazil toll-free: $080055-4777$

\section{- Delta Airlines}

In the U.S.

www.deltacom

U.S. toll-free: 1-800-241-4141

In Brazil

Brazil toll-free: $080022-1121$

\section{- United Airlines}

In the U.S.

wwwitualcom

U.S. toll-free: 1-800-426-5561

In Brazil

www.tnited com.br

Brazil toll-free:0800 16-2323

SăoPaulo

Av. Paulista 777, $8^{\circ}$ andar

Cerqueira César

CEP01311-100 
SãoPaulo, SP

Tel. (11) 3145-4200

Fax (11) 287.6444

Rio de Janeiro

Av. Atlântica 2600 1ำSubsolo

Copacabana-HotelMarriott

Rio de Janeiro, RJ

Tèl. (21) $2545-6575$

Fax (21) 2545-6580

\section{- American Airlines}

In the U.S.

wwwamericanairlines.com

U.S. toll-free: 1-800-433-7300

In Brazil

Brazil nationwide (not coll-free): 0300-789-7778

Porto Alegre

Av. Alberto Bins, 514

Porto Alegre, RS

Hours: Mon-Fri 8:30am-6:00p.m; Sat9:00a.m-1:00p.m.

- Varig Airlines

In the U.S.

www.varig.com

U.S. toll-free: 1-800-468-2744

New York

125 Park Avenue, Comer of 42 nd Street

Airline Satellite Terminal-Mezzanine

NewYork, NY 10017

Hours: Mon-Fri9 a.m.-5 p.m.

Tel. (212) $557-4872$

Miami

200South Biscayne Boulevard, Suite 650A

Miami, FL 33131

Hours: Mon-Fi9 a.m.-5 p.m.

Tel. (305) $377-8995$ 


\section{Los Angeles}

700 South Flower Street, Suite 1460

Los Angeles, CA 90017

Hours: Mon-Fri9 an.-5 p.m.

$\mathrm{Tel}$. (213) 688-1900

In Brazil

www.vatighrasil.com

Brazil nationwide (not toll-free) : 0300-788-7000

Porto Alegre

Ruados Andradas 1107

Hours: Mon-Fri9 am.6p.m;Sat9a.m.12 p.m

Tel. 3332-8799.

- TAMAirlines

In the U.S.

www.tam.com.br

U.S. tollfiee: 1-888-2.FYTAM

Adranta

6065 Roswell Rd Suite 532

Tel. (404) $236-0776$

Fax (404) $236-0138$

Miami - Airport

Teminal E (next to British Airways)

Otlando

1650Sand Lake Road Suite 209A

Tel. (407) 816-3555

$\operatorname{Fax}(407) 816-3502$

Washigton D.C.

1730 Rhode Island Ave NW, Suite 414

Tel. (202) 223-1751

Fax (202) 223-1753

In Brazil

wwwtam.com.br

Brazil nationwide (not toll-free): 0300-123-1000

Brazil nationwide (toll-free): 0800-562.211 


\author{
Porto Alegre-Aeroporto \\ Pça. Cnte. Carlos Rulh, s/n \\ Porto Alegre, RS90201-970 \\ Tel. (51) 3358-2050 \\ $\operatorname{Fax}(51) 33714479$
}

Porto Alegre-Plaza São Rafael
Av. Alberto Bins, 514, Centro
Porto Alegre, RS90030-140
Tel. (51) $3286-5834$
Fax (51) $3286-6410$

\title{
Brazil Air Pass
}

Both Varig and TAM offer the Brazil Air Pass, which gives you four or five flights inside Brazil to be used in a twenty-one-day petiod. Varig's Air Pass in August 2003 was U.S. $\$ 530$ for five flights, with an extraU.S.\$100 for each additional flight. Additional flights do not extend the period beyond twenty-one days, and you cannot buy less than five flights on Varig. TAM offers the same twenty-one-day deal for five flights, with the same $\$ 100$ price for extraflights, but italso allows you to fourflights for $\$ 430$. One thing to keepin mind is that twenty-one days is not a lot of time in which to squeeze in five destinations; for that reason, you might want to opt for the TAM four-flight deal.

There are several restrictions: (1) the pass has to be bought in conjunction with an alreadypurchased international ticketon any airline; (2) ithas to be bought from the U.S. before you leave; (3) you have to decide your destinations and the dates of all flights at the time of buying (youll incur a fine if you change either date or destination subsequently); (4) you can't pick the tickets up after you get to Brazil, so buy them soon enough before departing the U.S. for them to arrive in the mail; (5) you're not allowed to visit the same city twice; and (6) there are some restrictions on numbers of layovers and layover cities (e.g, if you fly from Rio to Belém, then to Porto Alegre, and then up to Manaus, with the requisite zillion layovers in the middle, they'll likely count it as more than threeflights). Since the rules are complex and subject to change, your best bet is to ask the ailline agent a whole lot of questions before you buy the airpass.

\section{Baggage weight limitissues}

Youneed to be prepared to deal with the different baggage weight limits for intemational hights and domestic Brazilian flights ifyour travel plans include either of the following two scenarios: (1) you had to buy two separate rickets to get all the way to Porto Alegre, one from the U.S. to Rio or São Paulo and the other from Rio or São Paulo to Porto Alegre; or (2) you're making a stopover in Rio or São Paulo before proceeding on to Porto Alegre or, if returning to the States, before proceeding home from Porto Alegre.

International flights generally allow two checked bags with a maximum weight of 32 kilograms each, plusone carry-on. Domestic Brazilian flights allow two checked bags, but witha maximum weight of 20 kilograms total, that is, an average of only 10 kilograms each. Twenty kilos is only forty-four pounds, which for most people is not enough for a full semester's worth of clothing. Additionally, you'll likely acquire heavy things in Brazil, such as books, that you'll want to take back with you. 
So if either of the above two scenarios applies to you, you may have to pay an excess baggage penalty (excesso de bagugem) for anything over twenty kilos, regardless of what airline you fly. If scenario \#1 applies (i.e., a simple layover), the solution is to buy the domestic portion of the ticket from the partner of the international airline on which you are flying and inform the domestic airline agent at check-in that you're flying internationally. In August 2003, Varig and United Airlines were intemational partners, and TAM and American Airlines were international partners. If, for example, you artive in Rio from the U.S. on American, youll probably have to take your bags to the TAM counter and go through a separate check-in process. Show the TAM agent your American boarding pass indicating that you just arrived on an international flight, and he will, in all likelihood, allow you to check up to 64 kilos at no additional fee. If you'te really lucky, American will check your bags all the way through to Porto Alegre from your U.S. departure city.

If scenario \#2 above applies to you (i.e., a stopover), you maynot be able to convince the domestic airline to letyou check the full 64 kilos at no additional charge. Your best bet, as in scenario \#1, is to buy both the international ticketand the domestic ticket from partner airlines.

If the domestic portion of your trip is on a non-partner airline (e.g., the international portion on American but the domestic portion on VASP), you will have to pay a rather stiff excess baggage fee, proportional to the number of kilos you are over the limit. Andeven some partner airlines, such as TAM and Taca (which flies from São Paulo to Peru and Central America), don'thave this baggage agreement. Your best bet is to inquire with both pertinent airlines beforehand.

\section{Domestic and intemational airports in Rio and Săo Paulo}

Something else you have to watch out for if you buy the two legs separately is that Rio and São Pauloeach have two amports. Rio'sintemational and domestic airport is called Gadeäo (GIG); its domestic airport, closer to downtown, is called Santos Dumont (SDU). São Paulo's intemational and domestic airport is called Guar thos (GRH) and is quite far from the center of the city; its domestic ainport is called Congonhas (CGH).

If your flight arrives into Galeão or Guarulhos and leaves out of Santos Dumont or Congonhas, respectively you're going to have to take a cab or inter-airport bus from one aiport to the other. Unless you're reallypressed for time, the inter-airport bus option is far preferable to takinga cab, especially in São Paulo, because it is a lot cheaper; the bus costs somewhere around U.S.\$5, and is air-conditioned, comfottable, and safe. In São Paulo it will take about an hour to get from Guarulhos to Congonhas or viceversa, and in Rio it will take abouta half an hour toget from Galeão to Santos Dumontor vice-versa. Make sure when buying your plane tickets to give yourself plenty of time between flights to be able to make this intra-urbanjourney.

Note also that the Brazilian ailine GOL, an analogre to Southwest or JetBlue in the U.S. which is usually the cheapest domestic option, does not fly to Guaruhos. If you fly GOL between São Pauloand Porto Alegreas part of an intemational trip, you will necessarily have to make the aitport switch. Fortunately, there is no such issue in Rio: GOLflies to both Galearo and Santos Dumont.

\section{Pline-buscombinations}

Another option is to fly from the U.S. to Rio or Sáo Paulo and take a bus from there; the bus companies will likely notcare how much baggage youbring along. I do notreconmend long-distance bus 
trips within Brazil, however, simply because the monetary savings do not seem to justify the extra hours it takes to get there and the hassle of taking a cab or urban bus, with all your bags, from the airport to the longdistance bus station to make the connection. For example, the bus ride from Rio to Porto Alegre takes twenty-four hours and costs aboutUS\$70. A one-way flight takes two hours (if there is no connection) and costs about US $\$ 100$. Ifyou insist on taking a bus, São Paulo is aboutsix hours closer to Porto Alegre than is Rio, thus making the ride a litle bit shorter and cheaper.

\section{Air travel within Brazil}

\section{General matters}

It goes without saying that Brazil is a massive county, and air travel is thus often the only feasible way to get from one place to another. As mentioned in the previous section, the monetary savings on longr distance bus trips probably do not justify the many additional hours it takes to get there. A one-way bus trip berween Porto Alegre and Rio is about U.S.\$70; a one-way flight is about U.S\$100, and will save you twenty-two hous and a considerable quantity of sanity. In my opinion, unless you specifically want to book at the landscape and visit towns along the way, the only practicable places to go by bus from Porto Alegre are those in Santa Catarina (e.g., Forianópolis, at six hours away) and perhaps Unuguay (Montevideo is twelve hours by bus).

Brazilian airports are generally very nice and easy to navigate; as is the case with the one in Porto Alegre, airports often double as shoppingmalls, complete with movie theaters. Unlike in the U.S., in Brazil one-way tickets are usually right around half the price of round-trip tickets. Additionally, buying a domestic ticket several weeks in advance of travel is usually not that much cheaper than buying it a week before; prices tend to nise slightly, however, for tickets bought within a week of travel.

\section{Choosing an aurline}

American Airlines Porto Alegre

Fernando Ferretti, Customer Service Agent

Hotel Plaza São Rafael

Av. Alberto Bins no. 514

Centro-Porto Alegre-RS

90030140

Tel. 3211-2088

Fax. 3211.3204

American Airlines São Paulo

Tel. (11) 3214.4000 or

(11) $0300-7778$

Brazil has four commercial ailines that offer nationwide service: Varig, TAM, VASP, and GOL. Varig and TAM are nicer and somewhat more expensive than VASP or GOL, and are roughly equivalent to each other in terms of ticket prices, safety, comfort, customer service, and available destinations. In fact, the two airtines merged in 2002 and are currently involved in a process of gradual assinnilacion into one another. Your flightexperience oneither Varig or TAMis likely to be pleasant. They also make good choices because they have U.S. partners (Varig is partners with United and TAM is partners with 
American ${ }^{17}$ ), allowing you to apply domestic Brazilian air travel to your frequent flyer account with the corresponding U.S. partner. In addition, if your domestic flight is part of an international flight on the domestic airline's parther, youcan generally check bags all the way through to your final destination, and intemational baggage restrictions - which are more generous than domestic restrictions-apply (see "Air Travel from the U.S. to Brazil", above).

One additional plus that comes from lying TAM/American is that both airlines have agencies in Hotel Plaza São Rafael at Av. Alberto Bins 514, in downtown Porto Alegre close to the UFRGS main campus. Fernando Ferretti, the guy that runs the American office, speaks impeccable English and is extremelynice. He's an excellent source for information on air travel within Brazil and between Brazil and other countuies, and can straighten out doubts aboutairline partners, baggage limits, layovers and stopovers, and frequent-fiyer-mile transfers. To get to Hotel Plaza Säo Rafael from the law school, walk up Rua Saumiento Leite to Av. Independência, cross Independência, turnleft, and take aright at the first corner (Rua Coronel Vicente). At the next block (Av. Alberto Bins) take a left, and the hotel is on the right.

VASP seems to slipping toward bankruptcy and has a bad reputation for having old and poorly maintained aimplanes. The one time I flew on VASP, the plane made strange noises that thad never before heardonan aimplane. You should probably avoid VASP

GOL (www.voegol.com,br) is Brazil's analogue to the U.S. arilines Southwest and JetBlue, and is agoodoption. It has anexcellent safety record and is generally cheaper than Varig and TAM. It does, however, have several disadvantages when compared to Vangand TAM: (1) ithas no U.S. partner and thus no option of wansferting frequent flyermiles; (2) it doesnot lly to Guanulhos in Săo Paulo, butonly to Congonhas; (3) while Varig and TAM serve full-fledged meals, GOL serves stale sandwiches and peanuts; ( 4 ) there's no firstclass; (5) due to the cheaper price, the fight is more likely to be jam-packed with people than a Varig or TAM flight would be; (6) for some inexplicable reason, there always seem to be more screaming babies on GOL than on the other airlines; (7) due to the cheaper price, customer service isn't as good as that of Varig or TAM, and GOL is less likely to make a policy adjustment in the interest of keeping the customer sausfied; (8) you can't buy GOL tickets online from the U.S.; and (9) GOLdoes not accept non-Brazilian creditcards on its website, in travel agencies, or at the airport. This last item means that you have to pay for your ticket in cash at a travel agent or at the airport.

\section{Payment options}

If you buy a Varig or TAM ticket as part of an intemational flight, you can use your U.S. credit cardon their respective websites (www.varigcom and www tam.com). You won't be able to buy domestic tickets online, however, without a Cadastro de Pessoa Física (CPF) number, Brazil's analogue to the U.S. social-securitynumber: See the secrion entitled "Getting a CPF" under "To "Take Care Of Soon After Arrival in Porto Alegre," above, for more details.

In the absence of a CPF, you'l have to go to the ainport, any travel agent, or a TAM or Varig office in town and buy the ticket in person. You can still use the websites to check prices, and the prices quoted on line will be the same prices they quote you at the travel agency (indeed, they usually buy the ticket through the same website that you would have bought it through if you had a CPF). On either TAMor Varig you can paywith your U.S. creditcard; each travel agent has its own special code that it uses in lieu of CPF.

"7 TAM is also partners with LanChile and Taca, which flies to Peru and Central America from São Paulo. 
On GOLit's a little more complicated. As mentioned above, GOLin nocircumstances will accept a non-Brazilian creditcard: not on its website, not at a travel agency, and noteven at the GOL counter at the airport. You have to take a big wad of cash with you to the tavel agent or GOL counter to buy the ticket.

\section{Bus travel within Brazil \\ Estação Rodoviária de Porto Alegre \\ Largo Vespasiano Júlio Veppo, $s / 1^{\prime \prime}$ \\ Centro \\ Tel. 3210.0101}

whwrodoviaria-poacombr

The long-distance bus station (estação rodorrária) on Largo Vespasiano Júlio Veppo, open 24 hours, has one section for intermunicipal (i.e, betweencities within Rio Grande do Sul) buses and another section for interstate and intemational buses. Buses are air-conditioned, comfortable, and sometimes have stewardesses and seats that urn into beds; the quality is about five million times better than that of Greyhound.

A bus to Montevideo costs around U.S. $\$ 58$ and takes 12 hours; to Buenos Aires U.S. $\$ 64$ and 20 hours; to Iguaçu U.S.\$41 and 15 hours; to Rio de Janeiro U.S.\$63 and 24 hours. As I have repeatedly stated, however, distances are so great in Brazil that, unless the destination city is very close (i.e., in Rio Grande do Sul, Santa Catarina, and perhaps Uruguay), the small amount of money you save by busing it instead of flying rarely justifies the extra time and frustration.

The bus option is, however, ideal for intrastate rips and trips to the coast of Santa Catarina A bus to Torres, Rio Grande's best beach, is U.S.\$10 and takes only three hours; a bus to Gramado, the quintessential touristy German town in the Serra Gaúcha, is U.S.\$8 and takes only two hours.

To get to the long-distance bus station from the lawschoo, walk up Av. Sarmiento Leite, cross Av. Independência, walk down the steps, and concinue walking for several blocks until just before the river: It's on the right side of the highway.

\section{Public transportation within Porto Alegre}

Porto Alegre reputedly has the cleanest and most efficient utban bus system in Brazil. There are somewhere around 300 bus routes that go from virtually anyplace in the city to any other place. Buses often have their own exclusive lanes (conedores), making bus traffic move faster than car traffic atcertain hours of the day. The standard bus fare at the time of writing in August 2003 was $\mathrm{R} \$ 1.45$, but you as a student can pay half-price if you buy the special tokens in advance. See "Getting Half-Price Bus Fare Tokens," under "Registering for Classes," above.

There is no single map of the 300 different routes, so figuring out what bus to take to get from where you are to a certain place can be a challenge. One solution is to dial the bus information holline at 158, toll-fice from anyphone, andask the attendant Another solutoonis to go to wwwportoalegre.rs.govbr, then click "Transportes e Circulação," then click "Serviços," then click "Itinerátios/TAB-Horárias." The "T" series of buses is particularly good; it includes nine buses, T1- T9, thatgo pretty mucheverywhere. T7, for example, connects Shopping Iguatemi and Shopping Praia de Belas, passing by a lot of popular places 
in between, including the UFRGS law school. At any tourist information bureau you can pick up the Guiade Bolso, which includes a map for each of the "T" bus routes.

Porto Alegre also has a series of redand white minibuses, called lotaçoes, that supplement the urban bus system, generally yunning from downtown out to one of the bairros. They have names, such as "Chácara das Pedras" or "Auxiliadora," and not numbers like normal buses; the name denominates the baimo that is the lotatyan's final destination. They are supposedly more comfortable than buses, but their superior comfort is debatable. They can feel cramped inside, they're hell in the summer if the AC is broken, and they can't use the special bus lanes, so they oftenget stuck in car traffic. Due to the supposed extra comfort, lotaçōes are considerably more expensive than regular buses; at the time of writing in August 2003, andecost $R \$ 2.20$. And you can't use hall-price sudent rokens on the lotaçöes; you'll always have to pay full price. Whenever possible, I opted for the bus over the lotaçäo.

Porto Alegre has a small metro that is of linited usefulness. It may, however, be a viable option if youneed to get from the airport to the bus station or vice-versa, and you don't have a ton of luggage.

Taxis are the way to get around after midnight, if youre in a hurry, or if you have a lot of stuff with you (such as grocerics or luggage). They always have a meter. When the city raises standard taxi fares, it takes a couple of months to adjust all the meters in all the taxis; in the meantime the taxi drivers cany a table with them that tells them how much above what the meter reads that they should charge. Always demand to read the table yourself; taxi drivers are notoriously unscrupulous with foreigners and will al ways try to screw you over. And even when you pay the official price, taxis are not particularly cheap in Porto Alegre.

\section{Drivingin Brazil}

Your U.S. driver's license is good in Brazil. You may, however, want to consider getting an Intemational Driver's License if you plan on doing a lot of drivingin Brazl or making a longroad trip, sinply because local police officets won't be familiar with the format of your state's license. An alternarive to an International Driver's License in this particular scenario is to take extra cash along on your road trip, to use as abribe for any highway patrol officer that pulls you over.

\section{Housing}

Finding good and reasonably priced housing can be somewhat tricky. MostUFRGS students, like Brazilian college students in general, live with their parents or some other family member: Students that come from cities and towns in the interior of Rio Grande do Sul (i.e., somewhere other than the Porto Alegre metro area) generally have one of three housing sicuations: they live with a family member, their family owns an apartment in Porto Alegre in which the children live while in college, or they rent an apartment, generally with roonmmates. There exist possibilities of paying a family to let you live in their house or renting a room in an apartment or house where otherUFRGS students already live (both of which are good if you want additional exposure to Portuguese), but these options generally have to be exploredafter arriving in Porto Alegre.

The thirdoption is to rentyourownapatment. Because, asstated, most students live with their families, the short-term apartment market in Porto Alegre is not very robust. The usual way to go about finding an apartment is by enlisting the assistance of an mobiliária (real estate agency), and two that are near the UFRGS main campus and deal with that area are Certa Imóveis ((51)3311-7800) and 
Guarida Imóveis ((51)3330-2929). But beware: most real estate agents, including these two, won't bother with you if you plan on renting the place for less than a twelve-month period, and furnished apartments are exceedingly hard to find.

The best solution that I could come up with is the Manhattan Studium Flat apartment bulding (3311-1100), at Av. Osvaldo Aranha 390, anextremely convenient five-minute walk from the law school just of the not theast conner of the main UFRGS campus in the Bom Fim batro (neighborhood). The apartments are almost all studio/efficiencies, although there are some with a wall between the bedroom and the rest of the apartment. They come in two sizes, large and small; in my opinion, the added space of the large apartment justifes the higher price. Every apartment is furnished with a bed with sheets, bankets and pillows; a closet; a bar or a table with chairs; a bathroom; a complete or semi-complete kitchen with at least a stove, refrigerator, dishes and cookware; air-conditioning; 70-channel cable TV; and a telephone. In addition, a maid comes every day to wash the dishes and clean the place.

You should ask to look at every available apartment before deciding which one you want, because the furnishings and their configuration vary greatly from apautment to apartment. Some apartments have any combination of the following added amenities: a balcony, acouch, a bar cond a table, a full-sized oven/stove combination, a cordless phone, a microwave, and a $T V$ thatcan be watched from bed or from the living room. The large apartments tend to have more of these things. I had a large apartment, Aprartment 807 , which had everythingbut a balcony (but ithada lot of windows to compensare), and it wasquite comfortable. Furthermore, the buildinghas agood in-houselaundromat withreasonable prices. One downside is thatyou can only make local landline calls from your apartment; you have to go to the payphone out on the street in front of the buildings to call cell phones or long distance, even toll-free "0800" numbers.

The Manhattan consistently had apartments available for the seven months I was in contact with the management; I think the demand for that kind of housing is low anong Brazilians and the price is admittedly somewhat lofty. The small apartments are officially $\mathrm{R} \$ 800 /$ month, and the large apartments areoficially $R \$ 900$ /month, butyou canalmost surelygetat leasta $\mathrm{R} \$ 50$ discountoneither. Added to that are electricity and telephone, which should be around US $\$ 20 /$ month and US\$10/month respectively, depending of course on how much you use the phone and the air conditioning. Coveredparking, should you need it, is an additional $R \$ 5$ per night. For me, the convenience of the Manhattan's location in the middle of the city dose to UFRGS combined with the dificulty of finding other housing gustified the price. The apartmentmanager's name is Paula; you can reach her at ((51)3311-1100 ext.254).

One word of warning: Paula is either very lackadaisical about calculating the bills, or she's malicious and wants to screw you over; I tend to think the latter is true. Scrutinize every bill mericulously. Becareful, for example, that your electricity bill does not include someone else's electricity.

\section{Money and banking \\ Cash}

The Brazilian cunency is the real (plural reais). The exchange rate at the time of writing in August 2003 was rightaround $\mathrm{R} \$ 3$ per dollat: Denominations of $\mathrm{R} \$ 1$ come either in a green bill, a big silver coin with a gold border, or a nondescriptsilver coin that is easily mistaken for a $\mathrm{R} \$ 0.25$ or $\mathrm{R} \$ 0.50 \mathrm{com}$. Fractions of a real are called centavos. $R \$ 50$ is the largest bill commonly seen, and even though it's only worth about US $\$ 17$, many stores and services won't take it for lack of sufficient change in the drawer. 
The mostconvenient way to obtaincash is by withdrawingt from your U.S. bank account via an ATM machine. Your ATM card musthave a Visa/Plus or MasterCard/Cirrus logo on it. If you don't have a bank account with a Visa/Plus ATM card, it's probably a good idea to open one before coming to Brazil. It is absolutelyessential that you know the PIN on your ATM card. You may alsobe asked for your authorization code or security code when purchasing certain goods or services (such as plane tickets) in Brazil; this code is the three-digit number at the end of asequence of numbers printed in the signature field on the back of your card. It's much better to withdraw money using an ATM/debitcard than it is to withdraw using a credit card. While your bank will charge you a dollar or two for each debitcard/ATM tansaction not made at one of its own branches, your creditcard company willikely charge you a higher fee for what's called a "cash advance"; it's something like U.S.\$5, plus interest.

Not all banks' ATM machines in Porto Alegre accept international ATM cards, in fact, few banks accept them, but the ones that do are sufficiently ubiquitous so thatgetting cash with an ATM card still remains the most viable option. The bestbank for ATM transactions is Bradesco; it accepts both Visal Plus and MasterCard/Cirns in all of its ATMs, and always gives the going exchange rate. Your second choice should be Banco do Brasil; Banco do Brasil also gives a fair rate, but ics ATMs that accept international cards are few and far between. Another bank that acceps international ATM cards is Banco 24 Horas. Additionally, at some locations of Banco Santander and Banco Billbao Viscaya there are international ATMs througha link to the Banco 24 Horas network. Citibank alsoaccepts them, but I don't tecommend it because there aren't many Citibank branches around.

The following are the addresses and telephones of the only four Citibank locations in Porto Alegre:
Rua24Outubro 355 , tel. $3395-1406$
Av. Nilo Peçanha2785, tel 3328-2481
Rua 7 de Setembro 722, tel. $3220-8500$
PraçaM.Cardoso 176, tel. 32224488

A list of the ten Bancodo Brasil bcations that accept intemational cards follows:

Azenha: RuaBt Triunfo 666, tel. 3217-1922

Bairro Anchieta: Av. Estados 1515, tel. 3373-1887

CistớvãoColombo

Fanrapos: Av. Farrapos 2505, tel. $3337-4099$

Moinhosde Vento

Passo da Areia: Av. Assis Brasil 2487, tel. 3341-2466

Praça da Alfândega

PUC

Shopping Praia de Belas

UFRGS

TheUFRGS Banco do Brasil is near the Reitotia and Lanches Antonio on the maincampus (at the intersection of Avenidas Paulo Gama and Osvaldo Aranha), a convenient three-minute walk from the law school; but beware: it's not open on weekends. Also beware that the Banco do Brasil at the UFRGSCampus do Vale doesn't accept intemational ATMcards. Downtown is full of banks, andalong 
two blocks of Av. Osvaldo Aranha, near the intersection with Av. José Bonifácio (on the edge of Parque Redenção), you can also find most of these banks.

Another word of caution: ATMs are usually located in a special room adjacent to the bank that, while its hours of operation are much longer than those of the bank itself, ustally closes around 9 or $10 \mathrm{pm}$ and may not be open on weekends.

While traveler's checks are an OKoption and are generally accepted at any bank or exchange bureau (casa de câmbio), I advise against them for three reasons: the exchange rate is usually bad because it includes the instritution's commission, you have to cash them during the institution's business hours, and you have to carry your passport with you when you go to cash them.

\section{Creditcard}

I reconmend bringing a Visa credit card as a supplement to a Visa/Plus ATM card; Visa seems to be the most widely accepted (it truly is "everywhere you want to be"). MasterCard is less widely accepted, followed by American Express. Anything else, such as Discover, is not likely to be accepted.

Mostchain stores and largenational services, such as depattmentstores (e.g, Lojas Americanas), stores in the mall (record stores, clothingstores, etc.), supermarkets, and airlines, accept Visa and perhaps MasterCardor American Express. But beware that some stores and services don't accept any foreign creditcards at all, andit's hard to predict which ones don't. Here are three important ones that won't take foreign creditcards: (1) any Brazilian aurline (GOL, TAM, Varig, VASP, etc.) where the ticket is bought over the internet for emission within Brazil; (2) the ailline GOL in any circumstance; and (3) the supermarket Zaffari. Beware also that if you buy clothing at a department store (such as C\&A) with a credit card, and later decide you don't want the clothing and try to return it for a refund, the store, while permitting you to exchange the item for something else, will likely refuse to refund your money.

Openingyour own bank account in Brazil

Banco do Brasil in New York

\section{PUTCONTACTINFOHERE}

If you decide toopen your own account with a Brazilian bank, the best choice is probably Banco do Brasil because it has branches all over the country and seemingly on every comer in Porto Alegre. Having a Brazilian bank account would solve several problems; (1) you could get a debitcard useable at the supermarket Zaffari and with the airline GOL; (2) you would save transaction fees for ATM withdrawals; and (3) you could use any Banco do Brasil ATM machine, and notjust the few-and-farbetween machines that accept international ATM cards. Banco do Brasil has a branch in New York, soyou could probal ly open your account there beforeleaving the U.S.; that way, if you need more money, your parents or someone else in the U.S. could deposit dollars into your account from the New York baanch.

One important word of warning: in order to open a bank account in Brazil, you'll first need a Cadastro de Pessoa Física (CPF) number, Brazil's analogue to the social-security number: Getting this number involves a process with the Receita Federal (Brazil's IRS equivalent), separate from any process you also have to go through with the UFRGS, the Consulate, or the Policia Federal; this is a good 
number to have anyway, even ifyou don'tcare about opening a bank account. See the section entitled "Getting a CPF" under"To Take Care Of Soon After Arrival in Porto Alegre," above, for more details.

Making deposits directly into someone else's bank account

Some services, especially thase located in another city, don't take cash or credit card, but instead require you to deposit the payment into their account at a specified bank. For example, in order to purchase half-price bus tokens, you have to deposit the payment into the city transportation entity's account at Bannisul; they won't take money over the counter. The same applies for any ree payment to the Registrar's Office (DECORDI); its bank of choice is Banco do Brasil. The service will give you its account number, which is usually typed on a slip of paper that the bank subsequently uses as a receipt to print the date and amount of the deposit. You simplypresent this slip of paper to the bank teller with the specified amount of cash, and then take the receipt back to the service to prove to them that you made the deposit.

\section{Telephone}

Brazil's councry code is 55. Porto Alegre's city code is 51. Phone numbers in Porto Alegre are composed ofeighe digits, always beginning with " 3 " if alandine and "9" if acell number Oldadvertisements maypresent phone numbers with only seven digits; if this is the case, add a "3" at the beginning. Note that some other Brazilian cities, such as Brasilia, are still on the seven-digit systen.

Here are some oher important city codes:

Porto Alegre: 51

SãoPaulo: 11

Rio de Janeiro: 21

Florianópolis: 48

Brasilia: 61

Salvador: 71

Recife: 81

Payphones (relefones priblicos or, more commonly, orelhoes) in Brazil are omnipresent, butonly abouthalf of them are actually operational, the other hal having been broken by vandals. You mutst buy a card (cartäo), avallable at moststores, phatrmacies, and newsstands, before you can use a payphone to call anything but a toll-free number (which always start with 0800); cards come in 20-4nit, 40-unit, and 60 -unit varieties. $A 40$-unitcard in August 2003 cost around $R \$ 5$.

If you're dialing locally, to a cell or to a landline, just dial the eight digits. If you're dialing longdistance inside Brazil, you must dial the foliowing sequence: $01+$ [ two-digit long-distance-provider code $]+[$ two-digit city code $\}+$ [number, usually eight digits]. There are a plethora of long-distance providers in Brazil, and some offer better rates than ohers. The two best long distance cantiers in terms of convenience are Embratel (21) and Intelig (23), because they can be used to dial any number anywhere in Brazil; the other caniers are regional. The country code of the United States is "1". If you're dialing the United States from a Brailian payphone the sequence is the following: $011+[$ two-digit longdistance-provider code] $+1+$ [U.S. area code] + [U.S. seven-digit number].

You mightget a three-minute call to the U.S. out of a 40 -unitcard. Calling cell phones within Brazil froma payphone is almost just as expensive as calling the U.S, giving you four or five minutes of talk 
time. Long-distance calls to conventional phones wirhin Brazil are not quite as expensive, and Brazilian local landline calls are actually quite reasonable.

Another option is to buy a cell phone and sign up for service. The problem with getting a cell phone, however, is that contracts usually have to be for a minimum of one year. If you can find some way to getaround the one-yearminimum, youmight ty Telefonica Celubr, tel. (toll-free) 0800-51-1404, or Claro Digital tel. (coll-free) 0800-51-1234.

\section{Intemet}

The UN Library at the UFRGS law school has three terminals you can use for free, but the internet is kind of slow. An altemative if you bring a computer to Brazil with you (which I reconmend) is to sign up for intemet service athome. The leading dialup service is Terra (wwwtetracom.br, tel. 3287 1000 ), and itcosts about $\$ 5$ per month, chargeable to Visa or MasterCard. Note, however, that there is no fixed monthly rate for local calls placed from home; you're paying - albeit a very small amount, roughly $\mathrm{R} \$ 0.03$-for each minute you're connected.

\section{Mail}

Mail in Brazil is somewhat slower than in the U.S., but not impossibly slow. To ship things faster, use the SEDEX service, analogous to U.S. priority mail, available at any post office. There are two speeds for shipping things to the U.S., economic and priority. Shipping the economic way costs about $\mathrm{R} \$ 50$ for five kilos, with $\mathrm{R} \$ 7$ for each additional kilo, and takes about a month to reach a destination in the U.S.

There are post offices all over the place. "The address of the central post office follows:

Agência Central de Coneios

Rua Siqueira Campos, 1100-Centro

Tel. $3220-8800$

Open 9am-6pmMon.-Friv, until noonon Saturdays

www.correios.combr

\section{Laundry}

The Manhattan apautment building has its own in-house laundry service (tel. 3311-1100, ext. 207) on the "SF" (saläo de festas) floor. The prices are very reasonable atsomewhere around R $\$ 3$ per kilo, $\mathrm{R} \$ 2$ to wash and ironadress shirt.

A good public laundromat which also offers dry cleaning near the law school is Lavanderia Bola Azul (Av. Independência 350, Porto Alegre, 90035-070, tel. 3224-0330). To giveyou an idea of the prices, it costs $R \$ 8.30$ to dry clean a pair of pants. Bola $\mathrm{Azul}$ is located on $\mathrm{Av}$. Independência between Barros Casal and Sarmiento Leite, roughlyparallel to the location of the Manhattan (which is three blocks downtill on Av. Osvaldo Aranha).

Houses of wotship

Catholic and Protestantchurches are ubiquitous in Porto Alegre. The following are the addresses and telephones of the temples of a few of the less taditional religions: 
- Associação Zen Budista de Porto Alegre

Rua Ivo Corcel, 169

Tel. $9986-7980$

- Centro Hebraico Rio Grandense

Rua FemandoMachado, 1008-Centro

Tel. 3225.1559

- Centro Israelita de Porto Alegre

Rua Henrique Dias, 73-Bom Fin

Tel. $3311-1935$

- Centro Cultural Istâmico (Mosque)

Rua Cel. Vicente, 382, sala 102

Tel. $3226-8458$

- Sinagoga Cinat Hatzedek

Rua Bento Figueiredo, 55-Rio Branco

Recreation andleisure

Restaurants

The following some particularly good restaurants in Porto Alegre:

- Acabit, Av. Independencia 827, between Rua Santo Antônio and Rua João Telles. Light and tasty soup and salad buffet, open all night long. Tel. 3311-9485.

Arte Pizza, Av. Casemiro de Abreu, 242, near intersection with Rua Miguel Tostes. Voted the best Pizza in Potto Alegre by Veja Magazine a couple of years ago, with good reason. I recommend the pizza "mafosa". Tel. 3330-8583.

$3225-1125$

Atelier das Massas, Rua Riachuelo, 1482. Italian restaurant with good pasta dishes. Tel.

Bar Ocidente, Av. Osvaldo Aranha, 960, intersection with Rua Gen. João Telles in the Bom Fim baino. At lunchtime Bar Ocidente is a vegetarian restaurant; on Sunclays it serves Inclian vegetarian food. Tel. 3312-1347.

Baum do Tra Non, Av. Protásio Alves, 966, on the turnoff that leads to Av. Nilópolis. Traditional fast-food joint, more than thirty years old. Serves only one kind of food: scrumptious bauru sandwiches. Tel. 3333-4447. Theydeliver:

Cafe do Ponto, Rua Padre Chagas, 293, nearMoinhos Shopping. Coolatmosphere and reallygood submarine sandwiches, even if slightly expensive. A good place for coffee with friends. Give the cheesecake a try. Tel. $3346-8385$.

Cavanhas, Av. Lima e Silva, 274, in the Cidade Baixa. The Xis-burnger (a Brazilian delicacy: a cheeseburger with your choice of toppings, such as peas, com, or chicken hearts) and chocolate pizza areexcellent. Tel. 3226-0743.

Chumascaia Barranco, Av Protásio Alves, 1578, nearintetsection with Lucas de Oliveira, Goodand classic barbecued meat place. Tel. 3331.61 .72$.

Landhes Ferreira, in the law school building, accessible fron the parkinglot. Much like Lanches Antônio, but with less selection, poorer quality, and less cordial service. But at leastit's really convenient. 
- Lonches Antôn Lio, UFRGS maincampus near the Reitoria. Vast variety of salgados, sandwiches, juices, hot lunches, and desserts. Good quality and cheap.

Monhatton, Edel Trade Center second floor, Rua Sarmiento Leite justacross joão Pessoa from the law school. Goodqualityper-kilo buffet. Tel. 3227-4680.

Pagroda, Av. Protásio Alves, 434, near the intersection with Av. Mariante. Inexpensive Chinese food, a la carte or buffet. Tel 3333-2333.

Prato Verde, Rua Santá Teresina 42, between José Bonifácio and Bonâncio Aires, Bom Fimbaim. Vegetarian food, as the name implies. Tel. 3333-6182.

Século, Av. Osvaldo Aranha, right beside Manhattan apartment building. "Tastyand cheap vegetarian Taiwanese food.

Sushi Express, Av. Mostardeiro, 121, intersection with Rua Miguel Tostes. Youllend up paying U.S. $\$ 10$ before it's over with, but the fresh salmon sushi and other Japanese delicacies are well worthit: Tel. 3395-2525.

Trrol, Rua José de Alencar,520. Goodselection of international cuisine. TeL 3231-5133.

ZCafé Bistrô, Rua Padre Chagas, 314, between Rua Dinarte Ribeiro and Rua Luciana de Abreu. Try the Beinute sandwich and the clericot: white wine with chunks of fruit. Tel. 3346-6088.

Bars

The following are some particularly good lyars in Porto Alegre:

- Bardo Beto, Av. Venâncio Aires, 876, in the Cidade Baixa baino near Hospital de Pronto Socorro. A bar and restaurant close to UFRGS, frequented by UFRGS students. Tel. 3332-0063.

Cherry Blues Pub, Rua Marquês do Herval, 52. First Irish pub in Porto Alegre. Lots of beer options. www.cherryblues.com.br/site. Tel. 3023-5252.

Dado Pub, Rua Fernando Gomes, 80, in the Moinhos de Vento bairn. Good selection of drinks, including "Dado Bier," a local brew that some say is tasty. Tel. 3395-1468.

Lourival, Rua 24 de Outubro, 1624, in the Auxiliadora bairro. Really good draught beer (chopp). Tel. 3337-3405.

Nightclubs

The following are some particularly good night clubs in Porto Alegre:

- Cabaret Voltaire, Av. Independência, 590. Alternative, sometimes GLS. Tel. $3325-1828$.

Dado Bier, Av. Túlio de Rose, 100, in Shopping Bourbon Country. Brews its own beer. Kind of expensive. Tel. 3378-3000.

Encouraçado Butikm, Av. Independência, 936. Tel. 3311-5090.

Liquid, Rua João Telles, 54, intersection with Av. Independência. Cool dance floor and good atmosphere. Tel. 3312-4432.

Pipe Pub, Rua Tobias da Silva, 241, in the Moinhos de Vento baimo. Expensive, chic, crowded, pretty cool. Go dressed up and go early, unless you're on the guest list or you enjoy waiting in line. Tel. 3346-2033. 
- Ocidente, Av. Osvaldo Aranha, 960, intersection with Rua João Telles. By day, vegetarian restaurant; by night, cool night club for gays, lesbians, and sympathizers. Tel. 3312 . 1347.

Opinião, Rua José do Patrocínio, 834, in the Cidade Baixa bairn. A classic. Bob Dylan played here once. Tel. 3211-2838.

Touch, Rua Túlio de Rose, 200. Tel. 3024-3929.

\title{
Fitness centets
}

If you're in the need for some physical exercise, a good fitness center is Hiper Academia at Av. Protásio Alves 1327, tels. 3388-6644 and 3388-6633, between Avenidas Vicente da Fontoura and Lucas de Oliveira. It has a Large weight room and a separate room with bicycles and treadmills; all equipment is well maintained. The gym also offers a considerable array of classes, including power biking, body pump, boxing, step, and samba and pagode. Its schedule is relatively accessible compared to most other gyms in Porto Alegre: Mon.-Fri. 6am-12 midnight, Sat. 9am-9pm, closed Sundays. Membership comes in three-month packages for around U.S\$60 total. Shorter contracts are also available for a proportionally higher price. To get there from the UFRGS main campus, wait at the Instituto de Educação bus stop on Av. Osvaldo Aranha across the street from the Manhattan apartment building, and catch any bus heading away from downtown that crosses Av. Vicente da Fontoura

\section{Dance classes}

One prominent dance studio you might check out if you want to brush up on your samba, pagode, or forro is Studio Paulo Pinheiro (Av. Barão de Amazonas 1050; tels. 3336-7182, 3315-0203; www.planeta.terra.com.br/arte/studiopaulopinheiro/studiodedanca.htm). There is also a flamenco studio two doors down from the Manhattan apartment building on Av. Osvaldo Aranha.

\section{Electricityissues}

Standard voltage in Brazil is $220 \mathrm{~V}$. In the U.S. it's only $110 \mathrm{~V}$, so if you plug a hair dryer or iron brought from the U.S. directly into the outlet (tomada), you might bum it out. Laptop connputers, battery chargers, and other electronic devices with their own voltage transformer (in computers it's in the cord) usually reduce anything ranging from $110 \mathrm{~V}$ to $220 \mathrm{~V}$ down to the appropriate voltage (e.g., $16 \mathrm{~V}$ for computers) automatically. For hair dryers and irons, however, you might want to consider buying a voltage reducer before leaving the U.S., available at electronic stores such as Circuit City and Best Buy.

Note also that Brazil uses two different types of prongs: Europectn-style round parallel prongs, and U.S.-style lat parallel prongs, almost never with the third tound ground prong. If the voltage-reduction kit that you buy before leaving the U.S. doesn't include a prongconverter, you can buy one once you get to Brazil for aroundUS\$. $\$ 1$.

\author{
MedicalMatters \\ Hospital Municipal de Pronto Socorro (HPS) \\ Av Osvaldo Aranhas $/ \mathrm{n}^{\circ}$
}




\section{BomFin}

\section{Tels. 192,3330-9998, 3316-9888}

There's a complex of hospitals adjacent to the main campus of the UFRGS, the campus where the law school is located. The main hospital for emergencies and other medical matters, however, is on the other side of Parque Redenção, also near the law school: Hospital Municipal de Pronto Socorro (HPS).

If you plan on doing any traveling through South America beyond southern Brazil, Argentina, Uruguay, and Chile, I strongly suggest that you get vaccinated for yellow fever and place the World Health Organization yellow-fever certificate (which happens to be yellow itself) with your passport. It's not so much that there's a bigrisk of catchingyellow fever, but that Brazilinu immigration requires that you be vaccinated if, prior to entry, you visited any of several northern Brazilian states or northem South Americancountries.

\section{Bookstores}

Porto Alegre has a vast anray of bookstores. Unlike withU.S. college towns, where there is at least one large bookstore whichsells all assigned books for all classes in all disciplines, no such bookstore exists in Porto Alegre. Thus, youll have to find the books you need atregular bookstores throughout town. The best new books bookstores are located in the better shoppingmalls, such as Boutton Country and Praia de Belas. Bookstores that specialize in used books are called becos, and you can find lots of them by just. strolling through the streets downtown. The following is a list of a few bookstores you'll definitely want to check out:

Bookstand in Lanches Feneira. There's a bookstand in the back of the law school snack bar that sells a small.selection oflegal books, some of which you mayneed for class, such as books by Professor Cezar Saldanhaand René David's comparative law book.

Livraria Cultura, Bourbon Country Shopping, Av. Túlio de Rose 80, Porto Alegre, 913140-110, livros@livariaculuracombr,wwwlivariaculturacombt. This is a massive bookstore in the Bourbon Counny mall, near Iguatemi off Av. Nilo Eeçanha, with tons of books (none of them used) and a great selection of CDs. The dictionary/grammar book section is particularly good. Unfortunately, however, the legal books sccion leaves something to be desired. Tel. 3028-4033.

Livraria Érico Veríssimo, Rua Jetônimo Coelho 377, Porto Alegre, 90110-241. Sells new, used, and rare books. Downtown, close to the law school, right across the street from Hotel Enlaixador" Tels. 3225-4624 and 3212-8022.

Livaria Saraiva, Praia de Belas Shopping, Av. Praia de Belas 1181, loja 5. Saraivacould be considered the main rival to Livraria Culnura. It's located in Praia de Belas, on the other end of the T7 bus route from Iguatemi, close to the Rio Guaba and not far from downtown. This is a huge bookstore with an excellent music and dictionaries section, and the legal collection here is much more extensive than that of Livratia Cultura. Additionally, in either Saraiva or Cultura, if they don'thaveit, theycanorder it for you. Tel. 3231-6868.

Sapien's. New and used books. Rua Coronel Vicente 527, tel. 3211-4966.

UFRGS Livtaria. The UFRGS bookstore is in Anexo I of the Reitona, right beside Lanches Antônio. Although it has a small selection of books and probably none of the books you'l need 
for class, it's a nice place to checkout and the place to go to buy UFRGS memorabilia (hats, coffee mugs, backpacks, etc.).

V.The Academic Environment at the UFRGS Law School

\section{Classes andexams}

Preparing for classes

As mentioned in an above section, study habits at the UFRGS Law School (and, for that matter, at Brazilian law schools in general), parallel undergraduate study habits in the U.S. much more closely than they parallel U.S. law-school study habits. Law school in Brazil is, after all, an undergraduate degree program.

Thus, law students in Brazil go to class to leam, and not (in most cases) to clarify what they've already learned in the readings or to think about new and anomalous applications of what was in the reading. There will often be some sort of reading accompanying each day's lecture, in the forn of an article the professor wrote in a law review, or a chapter from a general book on, say, Conflict of Laws; these readings, however, are usually not totally on-point and are thus only partially enlightening. There is never a casebook or an accompanying textbook per se; the closest thing to a text I had was a series of small books written by Professor Cezar Saldanha that pretty closely corresponded with what he taught in class.

Furthermore, you usually don't know what to read un til the day that subject is discussed, so any reading that you do takes place after the class discussion. One obvious implication is that you're not likely to know enough about the subject on the day it's discussed in class to ask informed questions or make informed comments. Indeed, classes in Brazilian law school, again like U.S. undergraduate, are lecture-intensive andalmost completely non-Soctatic; students have the habit of making very few comments and asking very few questions. Nevertheless, most professors do not frown upon student questions and comments. I, with my U.S. law-school Socratic conditioning, couldn't help but ask at least one "hut what if such and such were to happen?" question per day.

The sad truth is that most students probably don't read anything at all until two days before the test. As you must have done on innumerable occasions in undergrad, use your judgment when determining whether you really need to do acertain reading to understand the subject matter or do well on the test. Sometimes the readings are superfluous, and testquestions almost never expect you to draw completelyonaparticular reading.

Therefore, preparing for classes is, as a general rule, quite easy: just show up, with pen, notebook, and a copy of the Constitution. Take the Constitution with you everywhere; it will invariably be cited by the professor every day in every class, regardless of the class's subject matter. Moreover, you probably don't have to rush to make it to class on time; they almost always start fifteen to thirty minutes late. And almost nobody uses a laptop to take notes. If you feel you need your laptop, buy a long extension cord, because outlets are few and far between and the nearest one may be on the other side of the room. 
Exams (provas) are the most common form of evaluating students. Theoretically, two-hour classes will have one test at the end of the semester, and four-hour classes will have two. In addition to this regular test (or these two regular tests, in the case of a four-hour class), all professors give students who did poorly the first time around the chance to do a prowa de recuperaçäo to improve their grade. The regular test is usually administered two or three weeks before the beginning of the semester, and classes resume and continue for the next couple of weeks until the semester ends; consequently, the prova de recuperação usually covers more material, an incentive to do well on the first test and get it over with.

Exams come in two formats: essay (proxa dissertativa) and mulliple-choice (prova de questóes objetivas); essay exams are the most common, but in a four-hour class the professor (e.g., Professor Cezar Saldanha) might give one exam of each format. Essay questions vary greatly from professor to professor and subject to subject, but a strong understanding of what was discussed in class and an ability to re-articulate it in the exam is probably the key to success in most essay exams. Few will expect you to apply what was discussed in class to new and anomalous situations, as is the norm with U.S, law exams. Additionally, whether there will be a time constraint also depends on the professor (i.e., how much time he or she gives to finish the exam and how many questions he or she includes). In general, I felt little or no time pressure in my exams. Exams could last anywhere from an hour to three-and-a-half hours (as with Professor Cezar Saldanha).

There is no curve. Your grade is, however, posted publicly for the whole world to see. AC is needed to pass, which is a 7 on ascale of 1 to 10. ACin Brazilian law school is considereda very low grade. $A B$ is an 8 and an $A$ is 9 or above.

\section{Preparingamonografia}

A monografia is a research paper, with a minimum of perhaps fifteen pages, on a topic related to the subject of the class. You thoroughly explain an area of the law based on the writings of jurists, with some of your own observations occasionally thrown in. It is not a thesis. The professor neither expects nor wants you to advance a totally new argument.

Few professors actually assign a monografia as the sole fon nof evaluating students in a normal class; monografias are typically required for more monumental endeavors (e.g., you have to write one if you want to graduate with honors). Nonetheless, in the class Relaçöes Internacionais everyone had to write a monografia, upon which their grade was based almost entirely. Topics were given by the professor (who in this case was Professor Claudia) to complement the themes discussed in class, and included such subjects as the Intemational Court of Justice, the Protection of Cultural Heritage in Intemational Law, the WTO and Processes of Economic Integration, the Vienna Convention on the Law of Treaties, the International Regime of Trademarks and Patents, and the Intemational Criminal Count.

\section{Other ways of evaluating students}

There are, of course, other ways of evaluating students in addition to or in lieu of tests and research papers. Perhaps the most common of these is the in-class presentation, accompanied by a short (e.g, five-page) paper to be turned in to the professor. In such cases, the professor will often let you choose among several available ways to be evaluated. 


\section{Extracurricularactivities}

Intemshippossibilities

You have the opportunity to do a variety of internships while studying at the UFRGS law school. Professor Claudia and the other professors have connections with law firms and governmental agencies throughout Brazil, giving you the chance to go virtually anywhere and do virtually anything. It's just a matter of asking around to find out what's out there.

One already-established intemship for UFRGS law students that you can surely do is with the Centro de Apoio Operacional do Meio Ambiente at the Rio Grande do Sul Ministério Público downtown (about a ten-minute walk from the lawschool). The extemely competent director of the Support Center is Di: Sivia Capelli. You basically researchenvironmental laws and doctrine and make suggestions to environmental prosecutors throughout the state that have specific issues they need help resolving. Talk to Professor Claudia if you are interested in this internship.

If you anive in Brazil at least a few weeks before classes start, or stay after classes are over, and want to do an internship in Brasilia, there are several options. Professor Claudia can anange for you an intemship in the Consumer Law section of the Ministry of Justice (CADE), under the supervision of Dr. Roberto Pfeiffer You can probably also work, as I did, in the Special Secretariat for Human Rights, located in the Ministry of Justice building. Contact Herbert Batros, the Secretariat's sub-director in charge of interns, at hetbertbanos@mj.govbry explain your statusasanUFRGSlawstudent, andmention that (Jay Bischoff) gave you hise-mail. Getting exposure to Brasilia and the federal government was an extremelyenriching experience for me.

Whatever internship you do is highly unlikely to be remunerated and will not count for UFRGS law school credit. They are simply for self-edification.

\section{Grupos de pesquisa}

As an exchange student, you will automatically and involuntarily be a member of the $\mathrm{CNPq}$ "Mercosur and Consumer Law" tesearch group, coordinated by Professor Claudia. Widely regarded as the bestresearch group in the school, it is also the mostchallenging. You will probably be called upon to do at least one research project for Professor Claudia duringyour time at the UFRGS lawschool, and quality expectations are high. But the payoff is also substantial: Claudia's research-group students always rank among those that get the best internships, participate in international competitions, and study abroad. Being in Claudia's research group is also a good way to guarantee that you'll have the opportunity to talk to her at least once a week (it meets every Tuesday afternoon). Being in Professor Claudia's research group was for me an honor and a privilege; I was extremely lucky to have such an opportunity to work closely with one of Brazil's leading international jurists.

Otherprolessors have their ownesearch groups, the themes of which conrespond to the particular professor's area of interest. Professor Cezar Saldanhaleads the "Supremacy of the State" research group, and Professor Tupinambáleads a criminal law research group. If you want to be in any other research grou, in addition to Professor Claudia's, just ask the particular professor that teads it for permission. I can't imagine that he would refuse you admission. In general, professors are very receptive to exchange student participation in law-school activities. 
SAJU (Serviço de Assessoria Jurídica Universitária) is the main extension service of the UFRGS law school. It was founded in 1950 by law students seeking to guarantee free access to justice for the poor, in this sense it is most analogous to a clinic in U.S. law schools. SAJU's work is divided into several groups: family law, probate law, juvenile law, consumer law, and criminal law. Orientation is provided by professors and pro bono attorneys, and most of the legal duties (the writing of petitions, preparation of cases, etc.) are performed by UFRGS law students. To participate in any of the SAJU groups, send an e-mail to Verónica at saju@direito.ufrgs.br, or mention your interest to Professor Claudia.

\section{UFRGSMUN}

UFRGSMUN is the UFRGS Model United Nations, a student-organized event which takes place during three days every October and attracts law students from (theoretically) all over Brazil and the rest of the world. UFRGSMUN in 2003, for example, included students from Bhutan. Since the whole event takes place in English, if you're around in October or in the few months preceding the event, you'll likely be called upon to provide linguistic assistance. Whatever additional assistance you provide is up to you.

\section{Law Conferences}

Occasionally you'll have the opportunity to attend and possibly work at any of vanious law conferences throughout Brazil. One weekend each May the law school of the PUC/RS sponsors a conference in Gramado, a town in the Serra Gaúcha about two hours from Porto Alegre, which is famous for the partying that goes on the Friday and Saturday nights; the legal panels are also very good. There is also an annual international environmental law conference in São Paulo each June, organized by Professor Antônio Hermann Benjamin and the Lawyers for a Green Planet Institute. I worked at the conference on behalf of Professor Claudia's research group and the UFRGS law school in June 2003; the University paid for a portion of my travel expenses. This cvent is also a good way to get to know Professor Benjamin, one of Brazil's leading environmental jurists.

\section{The age difference}

As in most countries in the world, law in Btazil is an undergraduate major, and the course at UFRGS takes five years to complete. The typical student enters law school at age eighteen and graduates at age twenty-three, ready to goout into the world as a full-fledged lawyer (that is, once he passes the Brazilian bar exam). The UFRGS law school has two separate groups (turmas) of students, the morning turma and the nighttime turma. The morning turma follows the traditional age paradigm more closely: virtually all students are in their late teens or early twenties and do not work or only work part-lime. The nighttime tuma, on the other hand, has a larger proportion of nontraditional students: older students that have full-time jobs during the day and moonlight as law students; these students can be anywhere from eighteen to seventy years old. Even in the nighttime turma, however, the vast majority of students will be younger than you. 
The implications of the age dynamic are obvious. Youtre likely to have amote ample perspective than most of your classmates: you'll have written more papers, you'l have taken more tests, you'll have had morejobs and internships, and you'll probably be more mature. Andevenifyou hang out mainly with fifth-year undergraduates, older students from the nighttime tuma, and UFR GS LL.M. students, you'll still have to associate withnineteen-year-olds in class, inextracuricular activities, and at parties andother recreational events. This is just something to keep in mind.

\section{UFRGS Code of Conduct}

There is currently no official code of conduct in force at the UFRGS, although word has it that one is currently being debated. There is, however, a rule against alcohol on campus; at Lanches Antônio and Lanches Ferreira (the snack bar in the law school) you won't be able to buy a beer. The rule against alcohol is overlooked when there is some sort of on-campus banquet or other organized event.

\section{Law Library and UN Library}

The law library is located on the first floor of the law school building, in the middle of the rear hallway. The very helpful head librarian is Naila Touguinha Lomando. There are a couple of computer terminals which you can use to search for books. You'll need your UFRGS student $\mathrm{ID}$ (the blue one) to check out books (see "Getting Your TwoStudentIDs" under "Registering for Classes," above, to find out how and where to get this $(D)$. If you simply want to photocopy an article out of a law joumal, you can leave some form of $I D$ at the front desk while yougo downstairs to Guti Copy to doso. Overdue books R \$1 per day. When you enter the library, you't have to leave your book bag behind the front desk.

The UN Reserve Library is bcated in the basement, down the steps beside the entrance to the regular law library. It has a small collection of mainly UN-produced books and documents, which youll also need your UFRGS student ID to check out. There are three computer terminals, with internet access, that you can use for free. You can also print things out for $\mathrm{R} \$ 0.20$ per page. Professor Claudia's research group meetsevery Tuesday in aseminar room accessible from inside the UN Library.

\section{The "Xérox"}

Guti Copy is the official name of the place everybody refers to as "o Xérox"; it is located outside the law school beside Lanches Ferreira. You can also access it through a Dulch door just inside the entrance to the UNLibrary in the law school basement. Copies are a steal at $\mathrm{R} \$ 0.10$, and spiral bindings are just $R \$ 2.90$ (compare that to the whopping U.S.\$5.95 you normally pay at Kinko's). Most classes also have a pasta, a special folder kept behind the desk at Guti Copy with readings and other documents that the professor will assign at some point in the semester.

\section{RecommendedBooks}

The following are just a few of the books I recommend that you buy before leaving for Brazil or; as the case may be, soon after arrival.

- 5 em 1: Consturuçäo Federad, Códigos Civil, Penal, de Processo Civid, de Processo Penale Legistação Complementar Fundamental (2003). São Paulo: Editora Manole Ltda. It's probably agoodidea to have all these codes, and this is the onlybook I found thatconsolidates themall. It's available at Livtaria Cultura 
- Constituiçäo da Repriblica Federativa do Brasil (1988). The current Brazilian Constitution is an absolute essential; it will be cited by the professor at least once per day in $90 \%$ of your classes. Luckily, its also very easy to find; there's usually a copy of it printed at the front of any code (such as the Civil or Penal Code) or published compilation oflegislation.

David, René (1998). Os Grandes Sistemas de Direito Contemporâneo. São Paulo: Martins Fontes. This classic, which may be a requirement if you take Comparative Law, explains and compares the world's major systems of law in a clear and complete manner. If your knowledge of the civil law tradition is less than complete, it's probably a goodidea toread the section on the Romano-Germanic family oflaw before classes begin. Its only downfall is that ithas not been well updated since René $\mathrm{D}$ avid died quite some time ago; for example, in the section on U.S. law, it lists the minimum amount in controversy for removal to federal court as still being at U.S, $\$ 10,000$. It is avalable at the bookstand in Lanches Ferreira (the snack bar in the law school) and probably at either Livraria Cultura in Bourbon County Shopping or Livraria Savriana in Praia de Belas Shopping.

Marzano, Fábio (2002). Dicionáno Espanhol-Pontuguês de Falsas Semethanças. Rio de Janeiro: Editora Campus. The Spanish-speakinglearner of Fortuguese already knows that there are tons of words that are similar between the two languages that seem like they should have the same meaning, but they don't. For example, humo "smoke" in Spanishisfumaga in Portuguese, while fumo as a noun in Portuguese means "tobacco". This is the most complete dictionary of false cognates andorher specious lexical similarities between Portuguese and Spanish I have yet been able to find. It's a good tool for the Spanish-speaking leatner of Portuguese who is seeking to purify his Portuguese. It's avaliable at Livraria Culturain Bourlon Country Shopping.

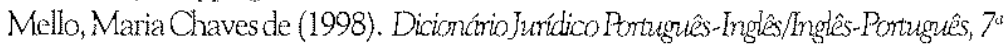
ed. Rio de Janeiro: Elfos. The hest Portuguese-English legal diccionaty that I have been able to find, it is available at larger bookstores in Porto Alegre, such as Livraria Cultura and Livraria Savriani.

Noble, John et. al (2002). Lonety Planet Braxil, Sthed. Melboune: Lonely Planet Publications. If you bring only one thing to Brazil, bring your passport. If you bring only two things, bring your passport and the exchange-student guide that youre holding in your hands right now. If you bring only three things, bring your passport, this guide, and the latestedition of Lonely Planet Brazl. It's available at bookstores everywhere in the U.S. If you for some reason don't buy it before leaving the U.S. you can also find it at Livraria Cultura in Bourbon Country Shopping in Porto Alegre.

Oliveira, Édison de (2001). Todo o mundo tem duirida, inclusive txê. Porto Alegre: Editora Sagra Luzzatto. This fun and easy-to-read book explains, in highlyundertandable terms, many of those tricky things about Portuguese that you and even most native speakers have a hard time dealing with (e.g., where to put clitic pronouns in different situations-te estarei dizendo, estareite dizendo, estarei dizendo-te, or estar-te-eidizendo?). I's available at Livraria Cultura or Livraria Savriana.

Perini, Mário A. (2002). Modem Pontuguese: AReference Grammar. New Haven: Yale U.P. A 621-page hardcover grammar book written for the native English speaker seeking to improve or perfect his Brazilian Portuguese. This book is very complete, easy toread, and loaded withenlightening examples; it also does a wonderful job of explaining the differences between spoken and written Brazilian Fortuguese. It's agood companion when writinglegal papers in Portuguese, and is worth bringing to Brazil with you despite the added weight in your luggage. Itcosts about $\$ 60$ and is avad able on wwwamazon.com And since it's the book of choice of the UT Portuguese Department for advanced phonetics and 
grammarclasses, if you're in Austinyou can also find itat the main banch of the Co-op among the books for the Portuguese classes. It's well worth the somewhat lofitypice.

Whitlam, Johnet. al., eds. (2001). Coltins Dicionánio Prático Inglês-Português PortugrtêsIngles. Glasgow and New York, HarperCollins Publishers. The medium-sized hardback is durable and quite complete while still manageable enough in size and weight to carry back and forth to school. It is available in bookstores in Porto Alegre and throughout Brazil and the U.S.

\section{Legal Glossary}

The following is ashort list of legal tems that commonly appear in Portuguese legal writings, and their approximate equivalents in English. For a complete list, purchase the Mello Portuguese-English legal dictionary at a local bookstore in Porto Alegre (see "Recommended Books," under "The Academic Environment at theUFRGS Law School," above, for more details\}.

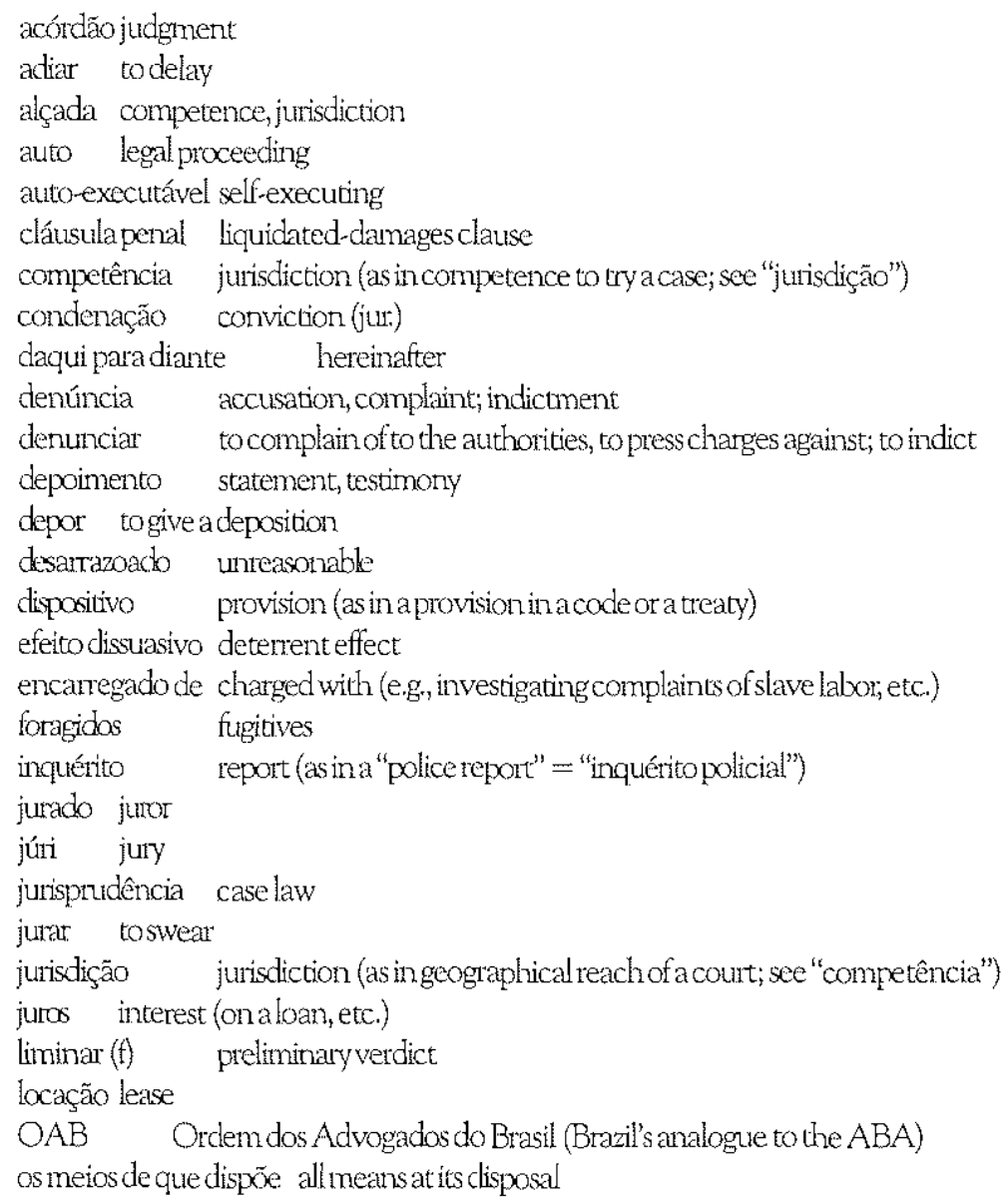




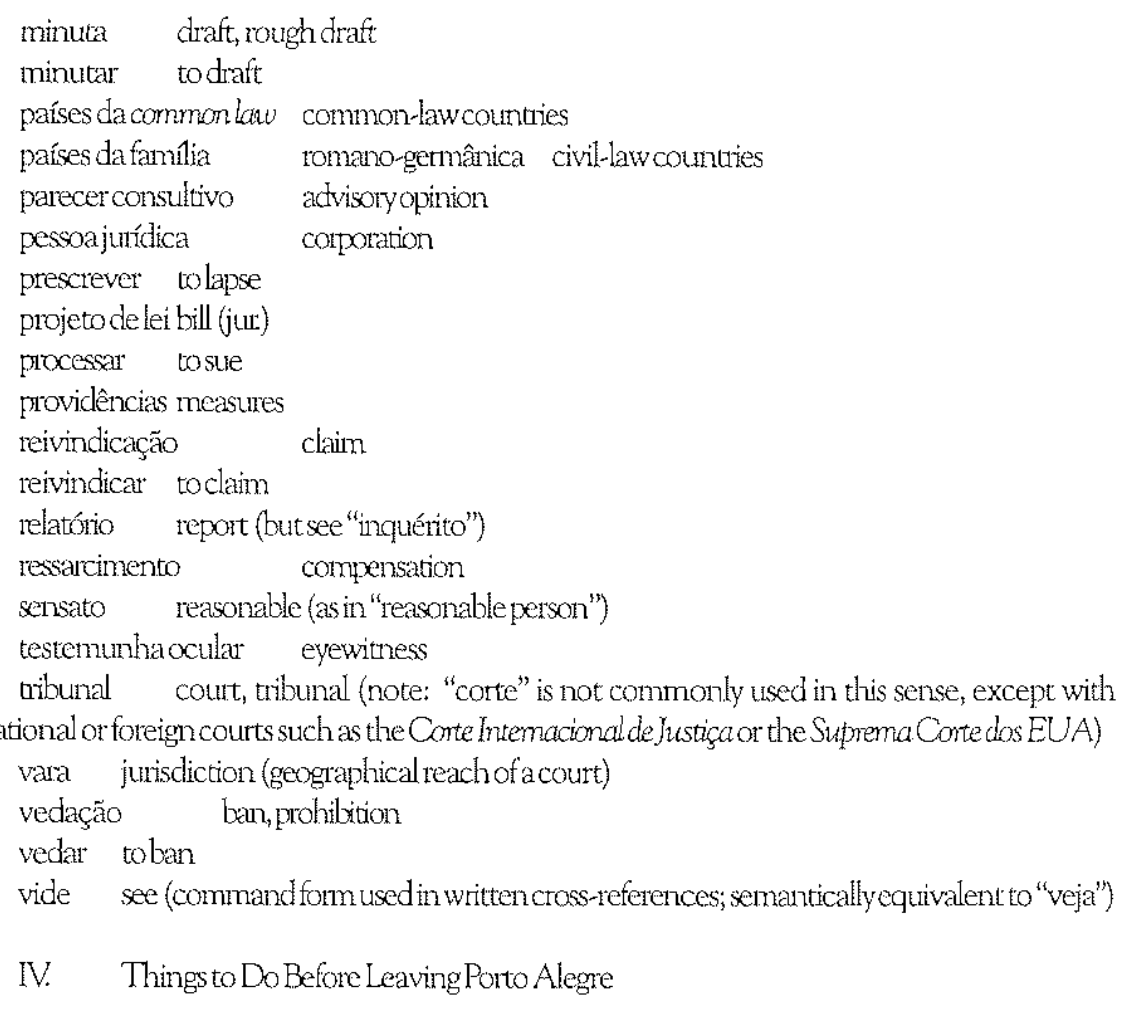

Getring an Official Transcript from UFRGS of the Classes you Took

Getting the document which explains the UFRGS grading system

UFRGS, like most U.S. institutions, uses a letter-based grading system. There are five possible grades (conceitos): $:^{18}$
A Ótimo/Excellent
B Bom/Good
C Regular/Average
D Insadsfatónio/Failing
Eor FF Falta de freqüência/nsufficient attendance

Registrar's Office:

Universidade Federal do Rio Grande do Sul - Pró Reitoria de Ensino

Departamento de Controlee Registro Acadêmico-DECORDI

Av. Paulo Gama, 110-Prédio 12106-Anexo Ida Reitotia

18 The grading system is set forth in Article 135 of the Regimento da Universidade (a booklet). 


\section{6-900-Porto Alegre-RS-Brasil}

It's a good idea to get an official letter from UFRGS explaining the grading system before retuming to the UnitedStates with your UFRGS transcript to requestacredit transfer. Go inperson to the Registrar's Office (DECORD), located in Rectory Annex I on the main campus (next to Lanches Antônio) and fill out the form "Solicitação de Documentos," requesting an "Atestado de sistema de avaliação." You will need your múmero de matricula, or at leastyour student ID so they can look up your student number: The lettercosts R $\$ 2.10$. They will give you a slip of paper which you then take to the nearby Banco do Brasil in order to deposit the R $\$ 2.10$ directlyinto the URFGS bank account; for some reason, they won't take the money directly. You then return to DECORDI with the bank depositreceipt.

Note that the letter takes two days to process. Youll have togo back to DECORDI inperson to pick up the letter, which will be in Portuguese, printed on official watermarked paper. An official translationinto English can supposedly be requested at the Biblioteca Central.

Getting yourofficial transcript

Unless youplan on hanging around Porto Alegre for a few weeks after the semester is over, you'll probably have to have Sívia Rochain Relaçöes Internacionais (relinter@ufrgs.br) mail you your transcript. She does this all the time. Just make sure you remind her before you leave toum, and send her a reminder e-mail a couple of weeks after you leave Porto Alegre. She'll send you as many copies as you need.

Important telephonesand websites

Emergencynumbers

- Brigada Militar: tel. 190.

- Corpo de Bombeiros: tel. 193.

- Hospital de Pronto Soconto: tels. 192, 3330-9998,3316-9888

- Polícia Civil: tels. 194, (51) 3217-2411.

- Polícia Federal, Delegação de Estrangeiros: tel. (51) 3358-9070.

\section{Transportation}

- Acroporto Intemacional Salgado Filho: tel (51) 3358-2000.

- Bus and lotação route hotline: tel. 158, www.portoalegre.rs.gov.br.

- Estação Rodoviária: tel. (51) 3210-0101, www.rodoviaria-poa.com.br.

\section{UFRGS contacts}

e-mail relinter@ufrgs.br.

Relações Institucionais e Internacionais: tel. (51) 3316-3902, fax (51) 3316-3973,

- UFRGS general: www.ufrgs.br/ufrgs.

- UFRGS law school: www.direito.ufrgs.br.

Airlines

- American Airlines: Porto Alegre tel. (51) 3211-2088, U.S. toll-free 1-800-433-7300, Brazil nationwide (not toll-free) 0300-789-7778, wwwamericanairlines.com. 
- Continental Airlines: U.S. toll-free 1-800-231-0856, Brazil toll-free 0800-55-4777, wwwcontinental.com www.delta.com.

Delta Airlines: U.S. toll-free 1-800-241-4141, Brazil toll-free 0800-22-1121,

GOLAirlines: wwwvoegol.combr.

TAM Airlines: Porto Alegre tel. (51) 3286-5834, U.S. toll-free 1-888-2-FLYTAM, Brazil nationwide (not toll-free) 0300-123-1000, Brazil nationwide (toll-free) 0800-562. 211, www.tam.com.br, www.tam.com.br.

United Airlines: U.S. toll-free 1-800-426-5561, Brazil toll-free 0800-16-2323, wwwual.com, www united.com.br.

Varig Airlines: Porto Alegre tel. (51) 3332-8799,U.S toll-free 1-800-468-2744, Brazil nationwide (not toll-free) 0300-788-7000, www.varig.com, www.varigbrasil.com.

Consulates andembassies

- Brazilian Consulate Ceneral in Houston: tel. (713) 961-3063, fax (713) 961-3070, e-mail consbras@brazilhouston.org, www.brazilhouston.org.

Brazilian Consulate General in New Yotk: tel. (917) 777-7777, fax (212) 827 . 0225, e-mail consulado@brazilny.org,www.brazilny.org.

- US. Embassy, Brasilia: www.embaixada-americana.org.br, tel. (61) 321-7272.

- U.S. Consulate, Rio de Janeiro: www.consulado-americano-rio.org.br/rio5.htm, tel. (21) $2292-7177$.

U.S. Consulate, São Paulo (serving Rio Grande do Sul): www.consuladoamericanosp.org.br, tel. (11) 3081-6511

Other

Turismo: tel. (51) 3388-7669, www.turismo.rs.gov.br.

Telephone information hotline: tel. 102.

Agência Central de Correios: tel. 3220-8800, www.correios.com.br. 